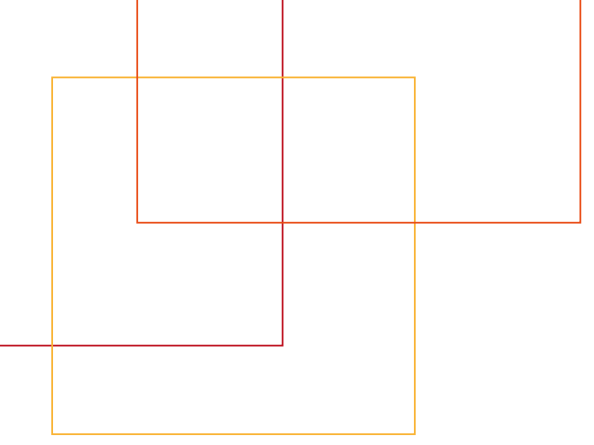

Working Paper No. 4 / 2015

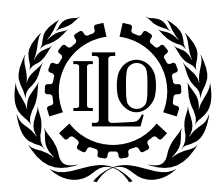

International

Labour

Office

Geneva

\title{
Cash transfer programmes, poverty reduction and empowerment of women in South Africa
}

Sophie Plagerson and Marianne S. Ulriksen

Gender,

Equality

and Diversity

Branch, WORKQUALITY Department

Social

Protection

Department 


\title{
Cash transfer programmes, poverty reduction and empowerment of women in South Africa
}

\author{
Sophie Plagerson and Marianne S. Ulriksen
}

Gender, Equality and Diversity Branch,

Conditions of Work and Equality Department

Social Protection

Department 
Publications of the International Labour Office enjoy copyright under Protocol 2 of the Universal Copyright Convention. Nevertheless, short excerpts from them may be reproduced without authorization, on condition that the source is indicated. For rights of reproduction or translation, application should be made to ILO Publications (Rights and Licensing), International Labour Office, CH-1211 Geneva 22, Switzerland, or by email: rights@ilo.org. The International Labour Office welcomes such applications.

Libraries, institutions and other users registered with a reproduction rights organization may make copies in accordance with the licences issued to them for this purpose. Visit www.ifrro.org to find the reproduction rights organization in your country.

Plagerson, Sophie; Ulriksen, Marianne S

Cash transfer programmes, poverty reduction and empowerment of women in South Africa / Sophie Plagerson and Marianne S. Ulriksen; International Labour Office, Gender, Equality and Diversity Branch, Conditions of Work and Equality Department - Geneva: ILO, 2015 (GED working paper)

ISBN: 978-92-2-129941-7 (print)

ISBN: 978-92-2-129942-4 (web pdf)

International Labour Office Gender, Equality and Diversity Branch.

cash benefit / family benefit / poverty alleviation / womens empowerment / household income / social assistance / South Africa

02.14 .2

ILO Cataloguing in Publication Data

The designations employed in ILO publications, which are in conformity with United Nations practice, and the presentation of material therein do not imply the expression of any opinion whatsoever on the part of the International Labour Office concerning the legal status of any country, area or territory or of its authorities, or concerning the delimitation of its frontiers.

The responsibility for opinions expressed in signed articles, studies and other contributions rests solely with their authors, and publication does not constitute an endorsement by the International Labour Office of the opinions expressed in them.

Reference to names of firms and commercial products and processes does not imply their endorsement by the International Labour Office, and any failure to mention a particular firm, commercial product or process is not a sign of disapproval.

ILO publications and digital products can be obtained through major booksellers and digital distribution platforms, or ordered directly from ilo@ turpin-distribution.com. For more information, visit our website: www.ilo.org/publns or contact ilopubs@ilo.org.

This publication was produced by the Document and Publications Production, Printing and Distribution Branch (PRODOC) of the ILO.

Graphic and typographic design, layout and composition, printing, electronic publishing and distribution.

PRODOC endeavours to use paper sourced from forests managed in an environmentally sustainable and socially responsible manner.

Code: DTP-JMB-REPRO 


\section{Table of contents}

Abbreviations ..........................

Preface. . . . . . . . . . . . . . . . . . . .

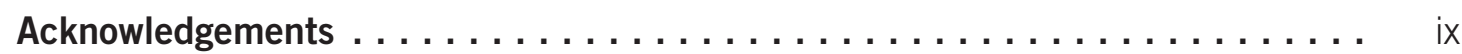

$\begin{array}{ll}\text { 1. Introduction } & 1\end{array}$

1.1. Overview. ............................. 1

1.2. Methodology ............................ 1

2. Cash transfer programmes in South Africa 3

2.1. Policy objectives of cash transfers . . . . . . . . . . . . . . . . 3

2.2. Main characteristics of the South African cash transfer system . . . . . . . 4

2.3. Administration, implementation and monitoring. ............. 6

3. Strategies and arrangements for cash transfers that aim

to reduce poverty amongst women and contribute to their empowerment

3.1. Gender-neutral but reaching more women. . . . . . . . . . . . . . . . . 9

3.2. Sustaining gendered positions. . . . . . . . . . . . . . . 11

4. Inter-linkages of cash transfers to other policies facilitating women's access to employment and social services $\quad 13$

4.1. Employment, skills development and social security . . . . . . . . . . . 13

4.2. Social services ... . . . . . . . . . . . . . . . . . . . . . . . 15

5. The effects of South African cash transfer programmes on women, with particular emphasis on their economic empowerment

5.1. Access to income, poverty alleviation and investment ... . . . . . . . . 19

5.2. Employment, labour market activities and migration . . . . . . . . . . 22

5.3. Household composition and child care ... . . . . . . . . . . . . 26

5.4. Intra-household decision-making. . . . . . . . . . . . . . . . 27

5.5. Health and education ......................... 28

5.6. Fertility rates . . . . . . . . . . 30 
6. Conclusion and recommendations 33

6.1. Conclusion .............................. 33

6.2. Recommendations ........................... 34

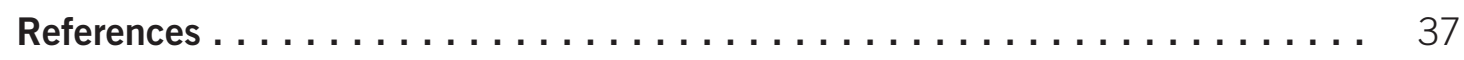

\section{Tables}

1. Social grants, target group, amount of grant and number of beneficiaries

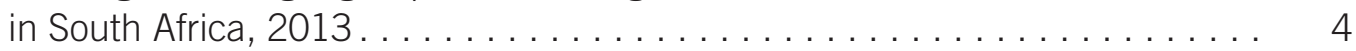

2. Expenditure on cash transfer programmes and welfare services,

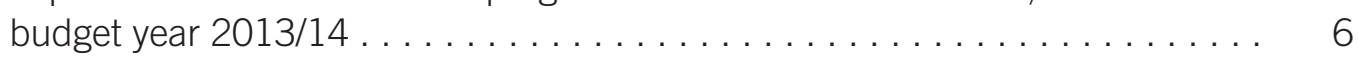

3. Active grant recipients, male and female shares . . . . . . . . . . . . 10 


\section{Abbreviations}

$\begin{array}{ll}\text { ABET } & \text { adult basic education and training } \\ \text { ANC } & \text { African National Congress } \\ \text { CDG } & \text { Care Dependency Grant } \\ \text { CSG } & \text { Child Support Grant } \\ \text { DG } & \text { Disability Grant } \\ \text { ECD } & \text { early childhood development } \\ \text { EPWP } & \text { Expanded Public Works Programme } \\ \text { HCBC } & \text { home- and community-based care } \\ \text { ILO } & \text { International Labour Organization/Office } \\ \text { OAP } & \text { Old Age Pension } \\ \text { RSA } & \text { Republic of South Africa } \\ \text { SA } & \text { social assistance and welfare } \\ \text { SASSA } & \text { South African Social Security Agency } \\ \text { SMG } & \text { State Maintenance Grant } \\ \text { UIF } & \text { Unemployment Insurance Fund } \\ \text { UNICEF } & \text { United Nations Children's Fund } \\ \text { ZAR } & \text { South African Rand }\end{array}$





\section{Preface}

Social protection plays a key role for gender equality and women's empowerment and social protection floors, in particular, can play a key role in closing coverage gaps for women. Aiming at preventing or alleviating poverty, vulnerability and social exclusion, social protection floors play a key role in economic and social development.

The Social Protection Floors Recommendation (No. 202), adopted in 2012, provides guidance to the ILO's 186 member States in establishing and maintaining social protection floors as a fundamental element of their national social security systems.

The 2009 International Labour Conference general discussion on Gender equality at the heart of decent work also recognised the role of social security in addressing poverty and inequality and concluded "Social security is a powerful tool to alleviate poverty and inequality".

Cash transfer programmes have been implemented in many countries as a key component of their national social protection floors and because these programmes provide a modest but regular income to poor households, they have the potential to reduce poverty and to enhance women's economic empowerment. The World Social Protection Report 2014-15 noted "Social protection is a crucial instrument in addressing all forms of poverty. Cash transfer schemes have successfully reduced poverty in Africa, Asia, Central and Eastern Europe, and Latin America, potentially delivering much faster results than those expected from the "trickle-down" effects of economic policies. Although in practice benefits have tended to be lower than needed, a cash transfer at an adequate level can bring people out of poverty overnight."

However, there have been concerns that the design of some cash transfer programmes may reinforce traditional gender stereotypes and thus constrain women's economic empowerment.

To examine these concerns and systematically identify good practices as well as any potential constraining factors, the ILO undertook a comparative analysis of large cash transfer programmes that are well known in development circles, namely in Brazil, Chile, India, Mexico and South Africa. This analysis considers not only the immediate impact of these programmes on poverty reduction, but also seeks to identify evidence on their longer-term effects and wider implications for various dimensions of women's empowerment, such as providing women with skills to enable them to enter quality jobs in the labour market, and including employment, income generation and care. These issues are highly relevant for the on-going deliberations on the importance of decent work, social protection and gender equality in the emerging post-2015 framework for sustainable development.

This comparative analysis aims to help the ILO generate new thinking on ways to improve the impact of cash transfer programmes on women's poverty alleviation and economic empowerment. It contributes to ILO's commitment to creating and extending social protection floors as reflected in the 2016-17 Programme and Budget and promoting more 
and better jobs for inclusive growth, the formalization of the informal economy, and protecting workers from unacceptable forms of work. It also provides useful knowledge for a set of good practice guides on social protection currently in preparation. The country studies are based on a review of the relevant literature on cash transfer programmes, including impact assessments, evaluations and other studies, as well as national policy documents. In addition, relevant data and statistics have been extracted from labour market and employment databases, social security statistics, time use statistics and other sources.

This working paper is one of the five country studies on cash transfer programmes and women's empowerment. The review of the South African experience in this study is complemented by country studies on Brazil, Chile, India and Mexico. Its results have also informed a comparative study, authored by Elaine Fultz and John Francis, and published in this series under the title of "Cash transfer programmes, poverty reduction and empowerment of women: A comparative analysis - Experiences from Brazil, Chile, India, Mexico and South Africa".

Shauna OLney,

Chief,

Gender, Equality and Diversity Branch,

Conditions of Work and Equality

Department.
ISABEL ORTIZ,

Director,

Social Protection Department. 


\section{Acknowledgements}

This working paper is a joint publication of the Gender, Equality and Diversity Branch in the ILO Conditions of Work and Equality Department and the ILO Social Protection Department, in cooperation with the ILO Decent Work Team for Eastern and Southern Africa and Country Office for South Africa, Botswana, Lesotho, Namibia and Swaziland in Pretoria. Christina Behrendt, Raphael Crowe, Chantal Dufresne and Luis Frota provided useful advice and guidance for this work. We also thank Leila Patel, Director of the Centre for Social Development in Africa, University of Johannesburg (South Africa) for her support of this work. 



\section{Introduction}

\subsection{Overview}

This country study of cash transfer programmes, poverty reduction and economic empowerment of women in South Africa forms part of a comparative analysis funded by the International Labour Organization (ILO); the other countries are Brazil, Chile, India, and Mexico. Through these five case studies and the comparison among them, the ILO aims to develop recommendations to promote the economic empowerment of women through social protection and strengthen the gender dimension in debates on the social protection floor.

The next section briefly describes the methodology used in this review of South Africa, while Parts 2-5 each answer specific questions. Part 2 gives an overview of the main characteristics of the cash transfer programmes in South Africa. Part 3 focuses on cash transfers from a gender perspective and analyses whether there are specific strategies and arrangements within the programmes that are aimed at increasing women's well-being and economic empowerment. Part 4 discusses inter-linkages between social grants and other policies that may facilitate women's access to employment and services. Part 5 provides an extensive review of the effects of the cash transfer programmes in South Africa. Finally, Part 6 concludes and offers a range of recommendations.

\subsection{Methodology}

In this South African case study, the overview of cash transfer programmes, strategic measures to reduce women's poverty and facilitate economic empowerment, and inter-linkages between social grants and other policies is drawn from national policy documents, national statistics sources, policy analyses and evaluation reports, and peer-reviewed literature. A survey of the impacts of cash transfer programmes in South Africa, with particular reference to gender and employment, was conducted following a systematic search of academic databases (Google Scholar, Eldis, Web of Science, World Bank) and South African institutions' websites (Human Sciences Research Council, Wahenga, Finmark, Centre for Social Development in Africa, Southern Africa Labour and Development Research Unit, Economic Policy Research Institute). The following key words were used to inform the searches: South Africa, gender, women, female, cash transfer(s), grant(s), social transfer(s), social protection.

Literature searches produced more than 70 relevant journal articles, book chapters and reports. This literature is reviewed with particular reference to gender. The majority of this literature concerns the most far-reaching cash transfers, the Old Age Pension and the Child Support Grant. Some studies have also investigated the impacts of the Disability Grant. The terms cash transfer, cash transfer programmes/schemes, social assistance and grants/social grants are used interchangeably. 



\section{Cash transfer programmes in South Africa}

This part of the literature review provides an overview of the social assistance system in South Africa. First, the key policy objectives of social grants are discussed, followed by a description of the main characteristics of social grants in terms of expenditure and coverage as well as types and levels of benefits. The last section gives more detail about the administration, eligibility criteria, payment mechanisms, implementation, monitoring and evaluation of the social grants.

\subsection{Policy objectives of cash transfers}

It is generally recognized that South Africa has one of the most progressive Constitutions in the world. In addition to civil and political rights, social and economic rights are also promoted and protected. Of particular interest for our purposes, Section 27(1) (c) states that "Everyone has the right to have access to [...] social security, including if they are unable to support themselves and their dependents, appropriate social assistance"(RSA, 1996).

However, the realization of social rights is subject to the availability of resources, and therefore it is envisaged that social security be achieved progressively with the prioritization of the needs of the least advantaged persons (Patel, forthcoming; Brockerhoff, 2010; RSA, 1996, section 27(2)). Social security in South Africa is provided primarily through social assistance and thus has a clear pro-poor focus. As explained in the Government's White paper for social welfare: "a social security system [...] is important for immediate alleviation of poverty and is a mechanism for active redistribution", and the main objectives of social assistance are poverty prevention, poverty alleviation, social compensation and income distribution (RSA, 1997, section 27(c); see also Patel, forthcoming; Jacobs et al., 2010).

Social grants have been an important tool for the African National Congress (ANC) government to redress historical injustices and inequities, but the particular focus on addressing racial inequalities that has been a priority in the South African context has to some extent overshadowed attention on gender inequalities and disparities, as will be discussed later. Supported by progressive legislation, coverage has increased, budgets have been raised and - quite uniquely (Lund, 2006a) - a new programme, the Child Support Grant (CSG), has been introduced (in 1998). Yet it is also important to acknowledge that the social grants system largely builds on policies developed from the 1920s onwards and that some of the main characteristics of this system remain, albeit no longer with a racial bias. Thus, social assistance is, still, targeted at the poorest and most vulnerable groups in society - the elderly, the disabled and the young, where access is subject to a means test; other parts of the population, most notably the unemployed and working poor, have limited access to social security (Devereux, 2011; Brockerhoff, 2010).

There is a curious mix of reluctance, incrementalism and progressiveness with regard to social grants in South Africa. On the one hand, grants are often viewed negatively - 
including by top ANC politicians and government officials - as hand-outs that create dependency and laziness (Marais, 2011; Surender et al., 2010). In 2010, conditionalities of school enrolment were attached to the CSG despite the fact that previously there had been no framework of conditionalities associated with grant receipt and that school attendance in South Africa is almost universal (Patel, 2012; Lund, 2011). On the other hand, the grants system has been expanded incrementally, most notably with the steady expansion of the CSG from benefiting only children under the age of seven to now benefiting all children under the age of 18 in poor households (Eyal and Woolard, 2011). It can in addition be viewed as quite progressive, and in line with the constitutional promise of progressive realization of social rights stated by the Minister of Finance, Pravin Gordhan, in the 2013 budget speech: "It is also proposed that the old age grant means test should be phased out by 2016" (Gordhan, 2013, p. 17). Should this proposal be implemented, one could argue that there is a shift in the character of the social grants system from means testing towards increasing coverage and ultimately universality.

\subsection{Main characteristics of the South African cash transfer system}

In terms of expenditure and coverage, South Africa has one of the most extensive cash transfer programmes in the developing world (Devereux, 2011; Woolard et al., 2011). Total social security expenditure (including social insurance but not public health) stands at 8.4 per cent of gross domestic product (ILO, 2010), with the cash transfer programmes amounting to 3.4 per cent of gross domestic product (RSA, 2013). Social grants in South Africa are fully publicly funded. The Government's budget for social grants has increased by an average of 11 per cent a year since 2008/09 (Gordhan, 2013), and social grants expenditure now covers 17.7 per cent of the Government's social budget and 10.5 per cent of total government expenditures. ${ }^{1}$

Table 1: Social grants, target group, amount of grant and number of beneficiaries in South Africa, as of September/October 2014

\begin{tabular}{llccc}
\hline Grant type & Target group & $\begin{array}{l}\text { Amount } \\
\text { of grant per } \\
\text { month (ZAR) }\end{array}$ & $\begin{array}{l}\text { Number } \\
\text { of grant } \\
\text { beneficiaries }\end{array}$ & $\begin{array}{l}\text { Share of total } \\
\text { beneficiaries } \\
\text { (\%) }\end{array}$ \\
\hline $\begin{array}{l}\text { Old Age Pension } \\
\text { (OAP) }\end{array}$ & $\begin{array}{l}\text { Persons over the age of } \\
60 \text { years }\end{array}$ & 1350 & 3026260 & 18.4 \\
\hline Disability Grant (DG) & $\begin{array}{l}\text { Persons medically } \\
\text { diagnosed disabled 18 } \\
\text { years or older }\end{array}$ & 1350 & 1124770 & 6.9 \\
\hline $\begin{array}{l}\text { Child Support Grant } \\
\text { (CSG) }\end{array}$ & $\begin{array}{l}\text { Paid to primary caregiver } \\
\text { of a child up to 18 years }\end{array}$ & 320 & 11480576 & 70.0 \\
\hline Foster Child Grant & $\begin{array}{l}\text { Foster families of children } \\
\text { under 18 years }\end{array}$ & 830 & 553223 & 3.4 \\
\hline
\end{tabular}

Author's own calculation (from RSA, 2013). Social grant expenditures include costs for grants as well as policy oversight and administration but exclude welfare services (see table 2). 


\begin{tabular}{|c|c|c|c|c|}
\hline Grant type & Target group & $\begin{array}{l}\text { Amount } \\
\text { of grant per } \\
\text { month (ZAR) }\end{array}$ & $\begin{array}{l}\text { Number } \\
\text { of grant } \\
\text { beneficiaries }\end{array}$ & $\begin{array}{l}\text { Share of total } \\
\text { beneficiaries } \\
\text { (\%) }\end{array}$ \\
\hline $\begin{array}{l}\text { Care Dependency } \\
\text { Grant (CDG) }\end{array}$ & $\begin{array}{l}\text { Parents, primary caregiver } \\
\text { or foster parent of a } \\
\text { disabled child who } \\
\text { requires permanent care } \\
\text { or support at home by } \\
\text { another person }\end{array}$ & $1260^{1}$ & 124225 & 0.7 \\
\hline Grant in Aid & $\begin{array}{l}\text { A person with a physical } \\
\text { or mental condition } \\
\text { requiring regular attention } \\
\text { by another person }\end{array}$ & $280^{1}$ & 96433 & 0.6 \\
\hline War Veterans' Grant & $\begin{array}{l}\text { Veterans of the two world } \\
\text { wars, Zulu uprising and } \\
\text { the Korean war }\end{array}$ & $1280^{1}$ & 366 & 0.0 \\
\hline Total & & & 16405853 & 100.0 \\
\hline
\end{tabular}

The South African Government currently distributes more than 16 million social grants, which means that almost a third of the population of 50 million people benefit from the social grant system. South Africa has seven different social grants: Old Age Pension (OAP), Disability Grant (DG), Child Support Grant (CSG), Foster Child Grant, Care Dependency Grant (CDG), Grant in Aid, and War Veterans' Grant (see table 1). The three main social grants in terms of reach are the Child Support Grant, the Old Age Pension and the Disability Grant; together they cover 95.5 per cent of the total number of grant recipients. When comparing numbers of grant beneficiaries to the latest census from 2011, coverage per population age group can be estimated as follows: grants for children (CSG, Foster Child Grant and CDG) reach 60 per cent of all children under 18 years of age. ${ }^{2}$ More than 4 per cent of the population between 18 and 60 receive the Disability Grant (the only grant for this age group), ${ }^{3}$ while about 73 per cent of the population above 60 get the Old Age Pension. ${ }^{4}$

\footnotetext{
The 2011 census data divide the population in age groups 15-19 and 20-24 years of age. Thus, assuming that there is an equal number in each age cohort, the share of child grants $(12,158,024)$ to the population aged $0-17(18,102,175)$ can be estimated to be roughly 67 per cent.

3 The share of grant recipients to the whole population aged between 18 and $60(29,516,625)$ is 3.8 per cent.

4 Population above 60 years $=4,151,760$ (Statistics South Africa, 2012, p. 28).
} 
Table 2: Expenditure on cash transfer programmes and welfare services, budget year 2013/14

$\begin{array}{lll}\text { Expenditure } & \begin{array}{l}\text { Expenditure } \\ \text { (ZAR billion) }\end{array} & \begin{array}{l}\text { Share of } \\ \text { (US\$ billion) } \\ \text { total SA } \\ \text { expenditure }\end{array}\end{array}$

(\%)

\begin{tabular}{lrcc}
\hline Old Age Pension (OAP) & 44.3 & 4.9 & 32.8 \\
\hline Disability Grant (DG) & 18.8 & 2.1 & 13.9 \\
\hline Child Support Grant (CSG) & 41.8 & 4.7 & 31.0 \\
\hline Other grants & 8.1 & 0.9 & 6.0 \\
\hline Provincial welfare services & 13.9 & 1.5 & 10.3 \\
\hline Policy oversight, grants and benefits administration & 8.0 & 0.9 & 5.9 \\
\hline Total social assistance and welfare services (SA) & 134.9 & 15.0 & 100.0 \\
\hline Total social service expenditure & 682.3 & 76.1 & \\
\hline Total government expenditure & 1150.0 & 128.2 & \\
\hline
\end{tabular}

Note: Exchange rate: US\$ 1 = ZAR 8.97 (30 April 2013 from: http://www.x-rates.com).

Source: RSA, 2013.

In monetary terms, the OAP, DG and CSG carry the most weight; costs for the other grants cover only 6 per cent of total social protection expenditure (table 2). Although the Child Support Grant of ZAR 290 (US\$32) is small compared to the Old Age Pension and Disability Grant of ZAR 1,260 (US\$140), the expenditure for the CSG is almost as high as for the OAP (ZAR 41.8 billion and 44.3 billion respectively), which is not necessarily surprising given the large number of CSG recipients. In this report we focus mainly on the OAP, DG and the CSG, as they are the most extensive social grants both in terms of coverage and costs. In addition, the OAP and CSG in particular have been extensively researched.

\subsection{Administration, implementation and monitoring}

In the past, it was the provincial departments responsible for social development that administered social assistance benefits. However, since 2006 the administration of social grants has been centralized under the South African Social Security Agency (SASSA). The Ministry and the Department of Social Development oversees SASSA's activities. The minister is ultimately politically responsible for social security, whereas the administration is accountable to the minister (Brockerhoff, 2010; Steele, 2006).

The eligibility criteria for the grants relate to citizenship or resident status and the applicant's income. Age is also a criterion. Beneficiaries of child grants must be under 18 years of age (although the actual recipient is an adult), while recipients of the OAP must be over 60 years. To benefit from the Disability Grant one must be between 18 and 59 years. Applicants for the DG must also provide a medical assessment report (for 
more details see the SASSA booklet You and your grants (SASSA, 2011) for the specific requirements for different grants). While applicants are required to provide certain documentation such as identity documents and birth certificates, the procedures have been significantly simplified in recent years (Devereux et al., 2011; Neves et al., 2009; Lund, 2008a). In 2012, SASSA began to re-register all social grant beneficiaries on a new biometric system, which should further improve the delivery of social grants and cut costs and the risk of fraud. ${ }^{5}$

Should an applicant be unsuccessful, SASSA must inform the applicant in writing of the reasons for refusal, and the applicant has a right of appeal (Devereux, 2011, SASSA, 2011). In the case of a successful application, the grant recipient can choose between a range of payment methods including payment into a bank account, at post offices, supermarkets and welfare pay points (Eyal and Woolard, 2011).

Particularly in the case of the CSG, which started rolling out from April 1998 onwards, there were many initial problems with administration and implementation. Many studies and monitoring reports documented problems such as differing application procedures, confusion regarding eligibility, difficulty in accessing appropriate documentation, understaffing, lack of vital equipment and so on (Eyal and Woolard, 2011; Goldblatt, 2005 and 2009; Goudge et al., 2009; Neves et al., 2009; Delany et al., 2008). Considering the many challenges documented in various reports and evaluations, including a recent SASSA-commissioned report to evaluate the CSG (Devereux et al. 2011), SASSA has admirably overseen a process of simplifying and improving its services over time.

Nevertheless, a range of challenges with regard to the implementation of social grants in South Africa should be noted. There are, for instance, still backlogs in grant approval and payment (Brockerhoff, 2010), and the appeal process has been delayed by inadequate funding from government (Devereux, 2011). Generally, there appears to be good knowledge about the eligibility criteria for grants, although there is often confusion about the details of the means test. Many believe that formally employed people are automatically disqualified, even though the income test relates only to the amount of income earned. Even though procedures have been simplified, it can be difficult and time-consuming to collect the necessary documentation, and in some cases such frustrations cause applicants to abandon the application process. Other problems include transport costs, lack of awareness and social stigma (Devereux et al., 2011).

Some problems regarding the implementation of social grants have gender-specific dimensions and are therefore worth mentioning. Female applicants/grant recipients are often in a subordinate position of power in relation to male officials as well as partners/ fathers of their child, and this situation creates barriers to accessing grants. It has been noted that some officials are at times known to treat applicants differently at their own discretion. Officials for instance sometimes refuse assistance to young women in the belief that the recipients are "wasting" a grant (Goldblatt, 2005), and some behave in a sexist and abusive manner towards the elderly as well as to young female applicants (Budlender and Lund, 2011). Furthermore, officials are known to insist that affidavits confirming maternity/paternity be issued at police stations, which are mostly staffed

See: http://www.sanews.gov.za/south-africa/social-grants-get-new-biometric-system-dlamini. The new system has also received some criticism, particularly for building up extensive databases that can increase governments knowledge of and control over citizens; see http://allafrica.com/stories/201407091348.html. 
by men, while these documents can also be issued by welfare offices (Lund, 2006a). Women, particularly those in rural areas, often depend on men for transport to the SASSA offices and pay points, and may be requested to provide proof that they have applied for alimony from the father, which can often deepen the conflict with the father and his family (Lund, 2006a; Goldblatt, 2005). However, as SASSA is constantly seeking ways to improve access to grants, it is entirely possible that some of these concerns have been addressed in the years since the studies referenced were conducted.

Compared to the able-bodied, people living with disabilities have specific difficulties and incur extra expenses; these include difficulties of access and inadequate facilities as well as additional transport costs. Women with disabilities are at a particular disadvantage, as they are more vulnerable and therefore at a higher risk of being abused, and - as disabled women are often also caregivers of a child or children - they may have to meet additional costs for child care while spending time on applying and accessing grants (Graham et al., 2010; Goldblatt, 2009). 


\section{Strategies and arrangements for cash transfers that aim to reduce poverty amongst women and contribute to their empowerment}

In this part, we consider whether there are specific strategies, measures and arrangements in the cash transfer system in South Africa that are aimed at reducing poverty amongst women and that contribute to the economic empowerment of women. Constitutionally speaking, women and men are equal before the law in South Africa, and unfair discrimination is prohibited. Cash transfers are gender-neutral and not necessarily aimed at reducing poverty amongst and enhancing empowerment of women per se.

Nevertheless, cash transfers in South Africa are indirectly related to the well-being and empowerment of women, but in two contradictory ways. On the one hand, more women than men receive grants, and therefore it is often implied that women benefit more from social assistance (Section 3.1). As discussed later (e.g. sections 5.1 and 5.4), cash transfers increase the incomes of women, which in turn may enhance their economic decision-making power within the households. On the other hand, it is also argued that social grants, particularly the CSG, reinforce traditional gender roles and therefore leave women in a subordinate position in society (Section 3.2). Thus, although cash transfers improve women's control of household expenditures, and have been shown to be associated with positive employment outcomes for some women, they can also be seen to support a traditional view of women as caregivers, thus detracting attention from the economic burden that women carry as providers for their households and the barriers they experience with regard to entering formal labour markets. We elaborate on these two trends in the following section.

\subsection{Gender-neutral but reaching more women}

The Child Support Grant is quite innovative in its design, as it encompasses two concepts that are gender-neutral yet cognizant of the South African situation: the concepts of "follow the child" and "primary caregiver". The idea is that the grant follows the child in that the child is the immediate beneficiary, yet the recipient of the CSG is the primary caregiver, who is defined as the person who takes primary responsibility for the child. This design takes into consideration the complex household structures in poorer households in South Africa where mothers are not always able to live with the child (for instance due to the need to migrate for work) (Budlender and Woolard, 2006; Lund, 2006b). Of course, the policy designers hoped that most caregivers would be the biological mother or father of the child, and that is indeed the case, with the large majority of CSG applicants claiming to be the mother (Lund, 2008b).

In cases where a CSG recipient is not the biological mother, she is often the grandmother, aunt or other female relative of the child (Budlender and Lund, 2011; Vorster 
have many positive effects, as discussed extensively in Part 5 of this paper. It has specifically been noted that social grant income has been important in reducing the extent and depth of poverty for female-headed households - more so than for male-headed households. In 2006 grant receipt reduced poverty in female-headed households by 16 per cent compared to 8 per cent in male-headed households (Posel and Rogan, 2012). However, Posel and Rogan also point out that, since employment had the largest marginal effect on poverty in their study and since earned incomes are relatively more important in male-headed households, female-headed households have experienced a relatively smaller decline in poverty rates. Hence, as female unemployment rates remain higher than those for men, and since men have higher average earning incomes than women there has been a widening of gender difference in poverty. According to these authors, in 1997 the difference in poverty rates between males and females was 4.7 percentage points (61.8 per cent of females lived in poor households compared to 57.1 per cent of males), while the gap had expanded to 7.3 percentage points by 2006 (59.6 per cent for females and 52.3 per cent for males).

Working-age women are rarely direct beneficiaries of grants (unless they are living with disability) and are usually not intended to be, as discussed in section 3.2. ${ }^{8}$ The most positive effects of grants therefore concern the broader family and particularly the wellbeing of the young, the old and the ill. It is suggested that grants still assist women in gaining some power in household decisions, in accessing the labour market and in providing options for income-generating activities, as discussed in Part 5. However, such impacts should not be exaggerated and could be seen as unintended side effects. For instance, most of the Child Support Grant (small in monetary terms) is usually spent on the children or as a general household budget top-up; grants are generally used for food, clothes for children, medical costs, school-related costs and transport (Patel, 2012; Devereux et al., 2011). Thus, it can be argued that positive consequences for women must be relatively minimal. Nonetheless, evidence showing that grants can empower women and enable them to access labour markets and/or generate additional income also implies that if additional cash grants were available to women directly, they would most likely be able to use these constructively, and the positive effects of grants would be stronger.

\subsection{Sustaining gendered positions}

In South Africa, as in many other countries, the "promotion of gender equality is often a secondary or indirect programme objective" of social grants (Holmes and Jones, 2010). It is assumed that women spend grants well for the benefit of the family and that grant receipt translates into empowerment of women (Sabates-Wheeler and Roelen, 2011). However, it can be argued that the CSG in fact reinforces the traditional roles of women and men in society in ways that disadvantage women.

Some scholars argue that whereas racial and socio-economic inequalities are considered critical developmental issues in South Africa, gender-based inequalities are neglected. Women have been shown to be generally poorer than men, more vulnerable and at higher risk of domestic violence and abuse. They also work more for less in both the

\footnotetext{
The feasibility of introducing a grant for pregnant women has been considered, see http://www.chp.ac.za/research/maternalearlychild/Pages/default.aspx.
} 
formal economy and the domestic sphere (Casale and Posel, 2005; Goldblatt, 2005; Bentley, 2004). Given their responsibilities for the welfare and health of (extended) family members, women often struggle to access the labour market and maintain their position therein (Lund, 2006b). It can thus be argued that the grant system could worsen the position of women, as it reinforces traditional gender norms and weakens their position vis-à-vis the labour market.

The phasing out of the State Maintenance Grant (SMG) in 1998 and the simultaneous introduction of the CSG is a case in point. The SMG was available to a parent or guardian living with a child under 18 years old. There were several criteria and conditions attached to the receipt of the grant, and, as there were differences in the rules and in their application, very few African children and their caregivers - the poorest segments of society - received the grant. As the post-apartheid government could not continue with a grant system that was racially biased, the CSG replaced the SMG. Unlike the CSG, the SMG had both a child and parent component (around 1998, the child grant was ZAR 135 and the parent grant was ZAR 430.) With the CSG - largely because of the need to reach more people - it was decided to emphasize the child rather than the carer, so the CSG does not include a direct benefit for the parent or guardian. It can be argued that the removal of the parent's component has gender implications, as by far most caregivers are women and since the caregiver's unpaid care work is no longer recognized and rewarded (Budlender and Woolard, 2006; Hassim, 2006; Goldblatt, 2005).

By no means a critique of the CSG nor advocacy for the SMG, which was highly problematic in itself (Lund, 2008a), the example in the previous paragraph highlights how social grants in South Africa support traditional expectations of women to provide unpaid care work. A similar argument can be made with reference to the Care Dependency Grant, which is given to parents or primary caregivers of a child living with a disability and who needs permanent care. This grant is awarded based on the assumption that care is given within the family, thereby avoiding expensive full-time institutional care (Lund, 2006a). Again, as women are usually the primary caregivers, they are expected to fulfil this role without any real compensation, and "there is the risk of viewing women merely as conduits for the delivery of services to children" (Patel, 2012, p. 18). It should, however, also be acknowledged that domestic care of children living with disabilities has positive impacts for the child, and therefore the grant can also be viewed as positive.

To summarize, although social grants in South Africa reach more women than men, grants are not intended to support the well-being and empowerment of women per se. Instead, with reference to the CSG, Goldblatt argues that "[w]omen mediate social assistance and deliver it on behalf of the state. They claim it, collect it and are then expected to turn it into food, shelter, clothing, education, health and other aspects of a child's maintenance through their own labours" (Goldblatt, 2005, p. 242). Given that employment policies and social services also provide only limited support to women, as we shall see in Part 4, women in South Africa face great challenges in bridging their double roles of poorly rewarded carers and productive economic agents. 


\section{Inter-linkages of cash transfers to other policies facilitating women's access to employment and social services}

In this part, we discuss possible inter-linkages between social grants and other policies that may facilitate women's access to employment services, health care, skills development and so on. We focus on two broad areas pertinent to the well-being and empowerment of women, namely: (1) employment, skills development and social security; and (2) social services. We also consider whether social grants are linked to these policy areas and the extent to which women benefit from them.

\subsection{Employment, skills development and social security}

Even though social assistance in South Africa reaches many women, the grant system is not directly linked to labour market and social security policies that could facilitate women's access to employment and skills development. In fact, as will be argued in this section, employment, social security provision, public works and skills development programmes are mostly disappointing from a gender perspective.

In South Africa, the employment-population ratio for women was 35 per cent and their labour force participation rate 48.3 per cent in 2013 (Statistics South Africa, 2013). There has been an increase in women reported as employed in South Africa, with 3.79 million women employed in 1995 compared to 5.97 million in 2013 (in 1995, 39.3 per cent of all employed people were women, and this figure rose to 43.8 per cent in 2013) (Statistics South Africa, 2013; Casale and Posel, 2005). As there are many more women wanting to work than available jobs, however, female unemployment rates have also risen. In the broad definition of unemployment, 38 per cent of all women who wanted paid work in 1995 were unemployed; this figure was 43.4 per cent in 2013 (ibid.). Under the narrow definition of unemployment (which excludes discouraged jobseekers), the unemployment rate for women today is 27.5 per cent, compared to 23.4 per cent for men (Statistics South Africa, 2013).

There have been some positive developments in that the number of women in the top income earner segment has increased (Casale and Posel, 2005). Nevertheless, an increase in employment figures for women is typically associated with low income and insecure positions with limited access to social security and few possibilities of advancement. Women are overrepresented in domestic work and self-employment in the informal sector, and they tend to dominate the most vulnerable and least lucrative strata of the informal economy (Budlender and Lund, 2011; Casale and Posel, 2002 and 2005; Valodia, 2001).

The Employment Equity Act of 1998 aims to achieve equity in the workplace and stipulates that employers must introduce affirmative action strategies that address the disadvantages suffered by women, black people and people with disabilities. It is likely 
that women have benefited from affirmative action in South Africa, particularly in larger corporations which are obliged to adhere to affirmative action policies, and in government institutions, where some women have advanced to senior management positions (Budlender and Lund, 2011, Valodia, 2001).

Formal affirmative action policies do not reach vulnerable workers in low-paid temporary employment and those in the informal economy (where the majority of workers are women). This is also mostly the case with social security provisions. The system of social insurance is largely linked to formal sector employment, which means that policies such as the Unemployment Insurance Fund (UIF) and medical aid and pensions schemes are unevenly distributed in ways that favour those working in the formal economy where men and whites are overrepresented. The UIF was amended in 2001 to include domestic and seasonal workers and to offer higher payments to lower-income workers - improvements that favour women. Nevertheless, even to the extent that employers of domestic workers adhere to the legislation, the number of people receiving unemployment benefits and other social security provisions in South Africa is very low. In the 2011/12 financial year, the South African Government paid UIF benefits to 706,000 people (RSA, 2013), a relatively small number compared to the scale of social grants which currently have around 16 million beneficiaries. Furthermore, as social insurance benefits generally favour those in formal and well-paid jobs, these benefits are still unevenly distributed to the disadvantage of poor women, who are overrepresented in low-paid jobs and in the informal sector (Woolard et al., 2011; Lund, 2006a; Lund, 2008a). The 4th Quarter Quarterly Labour Force Survey 2014 reported that unemployment rates remain higher among women than men (estimated at 38.3 per cent for women and 31.3 per cent for men) (DoL, 2015). The same report showed that among employed women, 23 per cent held skilled jobs, 42 per cent semi-skilled jobs, and 35 per cent unskilled. Correspondingly, among employed men, 22 per cent held skilled jobs, 55 per cent semi-skilled jobs, and 23 per cent unskilled.

Regarding public works and skills development programmes, the South African Government has run its Expanded Public Works Programme (EPWP) since 2004. The EPWP aims to provide vulnerable adults with the opportunity to obtain and practise skills in a working environment. Accessing the CSG could provide a gateway or referral for recipients to access other governmental initiatives. However, according to a study from 2008 , very few of the respondents had worked on a public works programme in the previous two years, and there was no statistically significant difference in levels of participation between CSG recipients and those not receiving the grant (Delany et al., 2008).

Launched in 2009, the second phase of the programme (EPWP II) included the social sectors of home- and community-based care (HCBC) and early childhood development (ECD) to improve access to care services, provide employment opportunities for women in the programme and promote professional development and skills training of people (mostly women) working in these sectors (Budlender and Lund, 2011; Jacobs et al., 2010). By 2009 the EPWP programmes had not fulfilled the target of providing women with 60 per cent of work opportunities as was suggested in the "code of good practices for special public works programmes" published in 2002 as part of the Basic Conditions of Employment Act (Budlender, 2009). The addition of HCBC and ECD in the EPWP II appears to have targeted more women than were targeted by EPWP.

However, it has also been argued that the inclusion of these social sectors was opportunistic, as many women were already doing HCBC and ECD work before the EPWP 
(Budlender, 2009). A number of other points of critique have also been noted in terms of the inclusion of HCBC and ECD in the EPWP II. First, wages paid in these sectors are extremely low even in comparison with other wages in public works programmes; in fact, payments are not even called wages but stipends and "mirror[s] the generally low value attached to most (female-dominated) care work" (Budlender, 2009, p. 33). Second, while training is important in these sectors - more so than in other parts of the public works programme, where training is often minimal or neglected - there are no jobs available after the training. There are few existing care organizations in rural areas, where the needs are greatest and where there is a huge lack of employment opportunities for women. The problem of actual employment positions in the social sectors is linked to a third issue - that enrolment in the programme is limited to a 24-month period. Thus, women receive substantial training but lose their income at the end of the programme, while the sector loses a trained person and thus receives minimal benefits out of the training resources invested (Budlender and Lund, 2011; Budlender, 2009).

There may be substantial hopes attached to public works programmes in terms of providing employment opportunities and incomes to poor and unskilled groups, including women. Certainly, the EPWP generated 1.6 million job opportunities between 2004 and 2009, whereas the target for EPWP II has been set at 4.5 million full-time equivalent jobs by 2014 (Jacobs et al., 2010). However, the EPWP is characterized as temporary work, where beneficiaries engage in short durations of employment at lower levels of pay than "normal" jobs, with no possibility of contributing to social security provisions such as the UIF. In fact, although some skills development is attached to public works and few may be able to move into "real" employment, public works programmes are "essentially poverty alleviation programmes, and cannot create sustained employment for the many" (Budlender and Lund, 2011, p. 936). In particular, from the perspective of the well-being and empowerment of women, the exceptionally low stipends for women who participate in these programmes and the few opportunities for actual employment afterwards means that "women derive almost no short-term material benefits from their participation" (ibid. p. 942).

\subsection{Social services}

Access to social services such as health care, education and housing are pro-poor in the sense that exemption from school fees, free access to health care and housing subsidies are intended for poor and vulnerable groups in a similar fashion to social grants (Lund, 2011). However, though CSG receipt is directly linked to school fee exemption (ACESS, 2007), in practice, grant receipt is not automatically linked to free or subsidized access to social services. For instance, while the CSG was intended to be complemented by access to other services and development measures, available evidence suggests that CSG recipients were only marginally more likely to access different services and poverty alleviation measures than non-CSG recipients (Lund, 2011; Delany et al., 2008). We will elaborate on this point in our discussion below of the links between the CSG and a range of social services. Facilitating these links can have a direct advantage for women, specifically as women are most likely to bear the brunt of poor access to services, such as water, which impact on the level of effort required within the domestic sphere.

With regard to education, a comprehensive review of the CSG showed that while school attendance is universally high, knowledge of school fee exemptions and how to apply for them appeared to be low. An issue of concern was that school fees were reportedly paid 
by two-thirds of grant recipients, despite a number of Department of Education policies aimed at removing the burden of this expense from impoverished households. However, CSG beneficiaries did tend to pay lower fees than those not receiving the grant (Delany et al., 2008). Still, the value of the grant is arguably being eroded when grant recipients use substantial funds on education-related costs such as school uniforms and transport (Patel, 2012; Budlender and Lund, 2011).

Knowledge about access to free primary and preventative health care measures for young children was high, with high levels of participation in immunization and growth monitoring programmes (Delany et al., 2008). A qualitative research report on the CSG (Devereux et al., 2011) showed that health fees vary substantially by type of service provider, with government being the cheapest and sometimes free. Discounts in health charges may be available, but these are not linked to receipt of the CSG (but rather to employment status or social groups, such as expectant mothers). Many CSG recipients spend parts of their grant income on health care for themselves and their families, such as consultation fees, medicine and transport to hospitals and clinics (Patel et al., 2012; Devereux et al., 2011)). Conversely, recent administrative innovations in health services, such as that birth certificates can now be issued in hospital immediately after birth, have facilitated access to the Child Support Grant (Devereux et al., 2011).

Understanding the degree to which inter-programme synergies are being realized is particularly important in light of a study on coping strategies of households with members living with a chronic illness, which showed that combined access to cash transfers (including disability benefits) plus access to free health-care services provided the best context. Those households with only one of these support components struggled and often fell into critical poverty (Goudge et al., 2009). In South Africa, the poor have access to free public health care, although the quality of care is sub-standard in most cases; private facilities providing care (whether for children, the sick or the elderly) are generally unaffordable and largely unavailable for poor households (Lund, 2002a), which means that care work becomes the responsibility of women in the domestic sphere who do not receive much compensation, as discussed in Part 3.

Beyond health and education, links between the Child Support Grant and other poverty reduction and developmental initiatives aimed at improving the quality of life of the household more broadly were weak. Few public social programmes are deliberately designed to connect grant beneficiaries with existing poverty reduction programmes, such as access to free housing; free basic services such as water, sanitation and electricity; assistance through municipalities for families that are registered as indigent; and developmental programmes such as adult basic education and training (ABET) (Delany et al., 2008). However, CSG caregivers (predominantly female) were no less likely to access these programmes than others living in the same low-income areas. Only small proportions of recipients and non-recipients indicated that they had registered with the municipality as indigent in order to receive assistance with basic services, with no statistical difference between the groups. Similarly, few respondents had accessed ABET classes despite the lower levels of education amongst the sample population. These low levels of take-up may be due to lack of information, lack of service provision or difficulties accessing the programmes (Delany et al., 2008).

In sum, there are few linkages between social grants and other policies that may facilitate women's access to employment, skills training, social security and social services. 
While the social grants system is extensive and reaches many women, social assistance is poorly linked to other strategies that may enhance the well-being and empowerment of women. 



\section{The effects of South African cash transfer programmes on women, with particular emphasis on their economic empowerment}

In South Africa, as elsewhere, the livelihoods of the poor are complex. Household configurations vary across space and time, many households are stretched across urban and rural locations, and household members are engaged in multiple and varied activities (Neves et al., 2009). Patterns of inter- and intra-household exchange are crucial to the efforts of poor households to capture opportunities and mitigate shocks. In the South African context, current gender dynamics are rooted in a broader gendered legacy: women are generally poorer than men and have higher HIV infection rates. Women carry a disproportionate share of responsibilities in the domestic sphere and experience high levels of domestic violence and obstacles, including lack of developmental opportunities and access to property, credit and skills (Patel, forthcoming; Goldblatt, 2005).

As was discussed in section 3.1, grants interact with gender in different ways. Take-up of the Old Age Pension is high amongst both men and women (Sienaert, 2008), although absolute numbers of female recipients are much greater than male recipients (Brockerhoff, 2010). In the overwhelming majority of cases, female caregivers access the Child Support Grant (Delany et al., 2008), although child beneficiaries are fairly evenly split between girls and boys (Brockerhoff, 2010). The Disability Grant has become increasingly feminized; in 2005, 54 per cent of DG beneficiaries were women compared to 45 per cent five years before (Goldblatt, 2009). Since then the level has stabilized, with 54.6 per cent of current DG grant recipients being women (see section 3.1).

The following sections review the effects of cash transfer programmes on women in South Africa, with particular emphasis on their economic empowerment, including access to income, investment behaviour, employment and labour market activities, household formation, autonomy in decision-making, and reproductive decisions.

\subsection{Access to income, poverty alleviation and investment}

There is general consensus in the literature that social grants have had a considerable impact on poverty (Woolard et al., 2011; Neves et al., 2009). Samson et al. (2004) concluded that, while the magnitude of poverty alleviation effects are sensitive to methodological issues (whether the poverty line is relative or absolute, whether it is scaled for household composition, and whether it measures income or expenditure), South Africa's social security system substantially reduced deprivation. For example, using a poverty headcount measure (the number of people in the country below an expenditure threshold), Samson and colleagues estimated a reduction in poverty headcount of 4.3 per cent attributable to the social grants. An alternative impact measure is the "rand poverty gap" (the rand (ZAR) is the South African currency). This quantifies the total value of the magnitude of the gap between the incomes of the poor and the income required to keep people out of poverty. Using this measure, researchers estimated that the cash 
transfer system reduced poverty by 45 per cent (Samson et al., 2004). More recently, other studies have reached similar conclusions. Using data from the 2006 General Household Survey, Posel and Rogan (2012) suggested that 64.3 per cent of all South Africans would have been poor had they relied only on income earned from employment, but that with the inclusion of social transfers, the extent of poverty fell to 59.1 per cent.

Woolard and colleagues also contended that, "[t]he expanded social assistance has had a substantial impact on poverty" (Woolard et al., 2011, p. 357). First, they found that social grants effectively target the poor: after disaggregating the population into quintiles, they observed that the percentage of households in the lowest quintile with access to social assistance rose from 16 to 64 per cent between 1997 and 2008, coinciding with the gradual roll-out of the CSG. Furthermore, the OAP and DG were of sufficient size to lift the majority of recipient households out of the poorest quintile. Secondly, Woolard and Leibbrandt (2010) indicated that government grant income significantly decreased the depth of poverty that those in the lowest quintiles would otherwise have experienced. They estimated that the mean poverty gap (an estimate of the depth of poverty expressed as a proportion of a poverty line) decreased from 0.47 in 1997 to 0.44 in 2008 (if incomes are taken to include social transfers) compared to an increase from 0.53 to 0.54 if grants are excluded from incomes.

The rapid expansion of cash transfer schemes has coincided with substantial increases (from 30 per cent in 1997 to 42 per cent in 2008) in the number of households with no link to the labour market (Woolard and Leibbrandt, 2010). The post-apartheid labour market has operated in such a way as to leave an increasing number of South African households outside direct access to employment or indirect access to remittance income from migrant workers (Woolard et al., 2011). Unemployment levels in South Africa are very high, yet unlike other countries with large reservoirs of surplus labour, the informal sector is small. In 2004, it was estimated that the informal sector absorbed only 19 per cent of the total labour force, compared to 50 per cent in formal employment and 31 per cent unemployed (Kingdon and Knight, 2004). In this context of scarce job opportunities, grants represent a stable source of household income. Improvements in material living standards are recorded for the OAP, the CSG and the DG respectively (Møller, 2011; Delany et al., 2008; Steele, 2006). It can be concluded that without government grants, poverty would have worsened rather than improved (Woolard and Leibbrandt, 2010). Rural households are the most reliant on grant income; urban households, many of which comprise recent migrants to the city, increasingly rely on a mix of income sources that dilute their dependence on social grants (Møller, 2011).

Gendered analyses of poverty trends over the period 1997 to 2006 show that the overall incidence of poverty in South Africa has fallen for both males and females. For both sexes poverty rates rose from 1997 to 1999 and then fell, particularly from 2004 to 2006. The reversal of the initial increase in poverty rates was driven particularly by the gradual roll-out of social grant income. However, the decrease has been absolutely and relatively smaller for females, and poverty estimates are significantly and consistently higher for females than for males. Gender differences increased over the decade. In 1997, approximately 61.8 per cent of females lived in poor households compared to 57.1 per cent of males. By 2006, poverty rates had fallen for both females and males, but the difference in their poverty rates had increased to 7.3 percentage points (59.6 compared to 52.3, see also section 3.1). A number of factors may explain the continuing gender disparities. Women's relative access to resources may have worsened 
due to the disproportionate effects the HIV/AIDS epidemic wreaked on them, rising rates of unemployment amongst them, and a persistent gender gap in real earned income. However, it is also important to recognize positive developments that have countered the widening gender gap since the transition to democracy; these include the introduction of progressive labour legislation and the increase in women's share of employment (Posel and Rogan, 2012). Above all, Posel and Rogan point to the role of social assistance in ensuring women's access to resources. They conclude that both the extent and depth of poverty are significantly lower than they would have been if households had relied solely on employment income, and that social grants have been particularly effective in decreasing gender differences in the depth of poverty. Similar findings apply to a comparison of female-headed and male-headed households: differences in the incidence and severity of poverty would have been even greater without the receipt of social grant income (Posel and Rogan, 2012).

Improvements in well-being are not uniformly experienced across all contexts and recipients. Particularly for the Old Age Pension, two mediating factors have been repeatedly identified in the literature: the gender of the recipient and the extent to which income is pooled within the household (Burger et al., 2009; Sienaert, 2008; Burns et al., 2005). Women experience an increase in personal income and the percentage of household income they control when they become eligible for the pension. The effect on increases in income is much less marked for men who reach pensionable age, as this coincides with labour force withdrawal and the fact that male incomes prior to receiving the pension are higher than female incomes (for men, average incomes before pension are comparable to the amount represented by the pension) (Ambler, 2011). Many studies have concluded that the pensions that women draw have larger effects (on welfare and labour migration, for example, as discussed in later sections) than those men receive. Household expenditure allocations differ according to whether resident pensioners are men or women (Case and Deaton, 1998) as discussed further below; for instance, grandmothers' pensions boost child development indicators much more significantly than grandfathers' (Duflo, 2000; Duflo 2003).

In many countries, including South Africa, growing evidence indicates that social transfers can help households improve livelihoods by investing some of the transfers they receive (Grosh et al., 2008). The regularity of payments facilitates access to credit and avoidance of inefficient insurance mechanisms (Keswell. 2004; Ardington and Lund, 1995). In South Africa there are few alternative policy instruments to address risk management, and social grants serve to fill this gap. Many households use grants to invest in funeral cover, although formal insurance against disability and the loss of income as well as short-term insurance tend to be extremely rare (Neves et al., 2009). Particularly in rural contexts, beneficiaries strategize to use grant income to secure credit, hire equipment and buy agricultural inputs. There is evidence of similar economic synergies in urban contexts, although these are more complex and less easy to capture (Du Toit and Neves, 2007). Other evidence from South Africa shows how savings from the state pension allows people to buy consumer durables, improve housing and invest in productive assets (Ardington and Lund, 1995).

Even though the Child Support Grant is significantly smaller than the Old Age Pension, research shows evidence of savings and investment. CSG recipients (predominantly female) are more likely to have bank accounts and some form of savings than those who are eligible but non-receiving. Of CSG beneficiaries, 42 per cent have a bank account 
compared to 24 per cent of eligible non-recipients, and 20 per cent report savings in some form versus 11 per cent of non-recipients (even though further research could help shed light on the causal directionality of the relationship between grant receipt and access to financial services) (Patel et al., 2012; Delany et al., 2008). Focus group data suggest that while savings levels are low, the CSG does enable recipients to participate in stokvels (informal mutual savings societies) (Neves et al., 2009).

A final income-related question regards the relationship between public and private transfers. Remittances continue to play an important role in the South African economy, in part because of the lack of government support for the unemployed (support mechanisms are limited to public works programmes and the unemployment insurance fund as discussed in section 4.1) (Klasen and Woolard, 2008). Lund (2002a) argues for the developmental effects of non-contributory old age pensions, and shows how these "crowd in" care of the elderly and of children, enhance household security, and stimulate the formation of very small businesses as well as local markets. This broad framework for understanding remittances is important in the South African context. Usually, remittances flow from a single working individual remitting funds to his/her family, rather than from a family sending resources to support an unemployed individual. The working poor bear the heaviest burden in providing for their even poorer friends, family, and neighbours, effectively creating a "tax" on income (Samson et al., 2002). There is some evidence that social transfers partially replace private transfers (Maitra and Ray, 2003; Jensen, 2003). Maitra and Ray (2003) find that the Old Age Pension partially replaces private transfers for poor households, while for the non-poor, private and public transfers complement each other. Jensen (2003) investigated the effect of social pensions on remittance flows and found that every publicly funded rand led to a 0.25 to 0.30 reduction in private transfers from children living away from home. In the broad context of widespread poverty, senders of remittances are frequently under economic pressure and therefore the reduced remittance burden can be viewed as a positive impact to be taken into account in the interpretation of these outcomes (Williams, 2007). A related issue that has emerged in reviews of the Child Support Grant is the problem of a lack of financial support from fathers who are no longer living with the mothers of their children. This places an enormous burden on women to provide financially for their children; it is also a critical factor in the persistence of child poverty in South Africa (Patel et al., 2012).

\subsection{Employment, labour market activities and migration}

South African women's share of the labour force increased from 41.8 per cent in 1995 to 48.8 per cent in 2005 (Van der Westhuizen et al., 2007). Yet this sustained feminization has also been associated with rising levels of female unemployment (see section 4.1); increased female representation in low-paid, insecure forms of employment (of the 1.4 million additional jobs recorded for women between 1997 and 2003, over 60 per cent related to self-employment in the informal sector or domestic work); and only a small increase in female representation in the formal sector (the number of black African women in professional occupations grew from 69,000 in 1995 to 130,000 in 2003) (Casale and Posel, 2005; Casale and Posel, 2002). Reasons for this disproportionate increase in supply of rather than demand for female labour include increasing levels of education, a decrease in fertility rates, a decline in the income of men to which women might have access and the increased number of female-headed households (Van der Westhuizen et al., 2007, Casale and Posel, 2002). Gender disparities also charac- 
terize the returns to work for women, for example hourly earnings continue to be lower for women than men (Budlender and Lund, 2011).

In this context of the feminization of labour participation and unemployment, a number of studies have investigated how cash transfers interact with labour supply. Evidence of the impacts of Old Age Pensions and Child Support Grants on labour supply includes findings on generational effects, changes in household configurations, migration trends and gender differentials.

Overall, as a result of social grants, Burger et al. (2009) observed a lower labour participation amongst older generations and higher participation amongst younger generations. As could be expected, the Old Age Pension is generally associated with withdrawal from the labour market (Neves et al., 2009). Studies that examine the labour supply of elderly pension-eligible adults found that labour participation rates decline steeply for both men and women at their pension eligibility age thresholds (Ranchhod, 2006; Lam et al., 2005), although the sharp jump in retirement is not as large as that observed in many European countries (Lam et al., 2005).

The effects of social pensions on the working-age population have been broadly debated in the literature. Crucially, findings depend on assumptions regarding household configuration and migration behaviour. In a study conducted in 2003, Bertrand and colleagues concluded that pension receipt was associated with a substantial reduction in employment by working-age individuals living in rural, three-generation households containing pension-eligible individuals (Bertrand et al., 2003). They found that social pension eligibility in the household was associated with a greater reduction in male than female labour supply and that female pensioners reduce labour supply more than male pensioners (Sienaert, 2008). Posel et al. (2006) revisited Bertrand et al.'s 2003 study using the same data and methodology but included non-resident members. They suggested that the previous results were weak as a result of an inappropriately restrictive definition of the household and because they neglected the potential labour supply response of those who move for work, which is important in the South African context. In the aggregate, they found that pension eligibility has no household labour supply effect. Summarizing, they concluded that they found "no convincing evidence that the social pension creates disincentives for prime-age individuals to migrate to work or to find work" (Posel et al., 2006, p. 852).

Sienaert (2008) also underscores the importance of taking into account migrant effects. His study showed that receipt of the Old Age Pension was associated with modest negative impacts on participation and employment probabilities amongst prime-age individuals in pension-receiving households. Yet by comparing estimates restricted to resident household members with those including non-resident members, he showed that if migrants are included amongst labour force participants and the employed, the gap in labour force participation between recipients and non-recipients is almost eliminated. Sienaert interpreted the declines in employment probabilities, suggesting that the pension enables a switch out of undesirable states such as costly job search and unpleasant employment. Thus, while the option to be more selective about accepting jobs may reflect a decrease in employment rates, it may actually be economically beneficial in the longer term (Williams, 2007). From a different angle, Klasen and Woolard (2008) reflect that unemployment restricts the ability to set up independent households, caus- 
ing the unemployed to remain in their rural households with parents or other relatives, thereby reducing their search activities and employment prospects.

Other studies have shown more positive overall associations between pension receipt and employment for working-age adults. Ardington et al. (2009) observed a small increase in the employment of working-age adults once pension receipt begins in their households ( 3 per cent change in employment status on average for resident and nonresident, prime-aged men and women), with large effects on migration and a significant decrease in labour migration in households that lose pension eligibility (on average, individuals from households that lost pension status were 4 to 6 per cent less likely to become or remain working migrants. Individuals from households that gained pension status were 4 to 5 per cent more likely to become or remain migrants.) Similarly, Samson (2009) found that working-age adults in poor households who receive a social pension are more likely to look for and find employment than their counterparts in nonrecipient households. The strong rural-urban dynamic of labour migration in South Africa is driven by the absence of local employment markets in rural areas (Jacobs et al., 2010), a differential that generates high costs and considerable constraints to jobseeking (Klasen and Woolard, 2008).

Gender is a central theme and interacts with both labour and migration trends associated with pension receipt. The sex of the pension recipient has strong implications for labour outcomes. The effects of pension receipt on labour supply are typically strongest in the case of pensions received by women (Sienaert, 2008; Posel et al., 2006; Dinkelman, 2004; Inder and Maitra, 2004). Moreover, positive migrant supply effects stemming from pension receipt are far greater for working-age women than for their male counterparts (Ardington et al., 2009; Posel et al., 2006; Keswell, 2004). Dinkelman (2004) found that the numbers of male and female pensioners both exerted negative impacts on adult male labour supply. Adult female labour supply is decreased by the presence of male pensioners, while older females' pension receipt has a strong positive impact on the labour force participation of other women. Disaggregating by gender, Posel et al. (2006) similarly observed that black African women were significantly more likely to be migrant workers when they were members of a household in receipt of a pension, especially when the pension recipient is female. Ardington et al. (2009) documented that the presence of a woman pensioner promotes labour migration for both men and women (consistent with female pensioners pooling their income with prime-aged members of both sexes), and that the presence of a male pensioner promotes labour migration, but for prime-aged men only. Disaggregating by age, Edmonds et al. (2005) specified that female pension eligibility is associated with an increase in the number of women aged 18 to 23 (that is, around typical first motherhood age) and a decrease in the number of women aged 30 to 39 in households.

There is consensus in the literature that pension receipt enables households to overcome both financial and child-care constraints to jobseeking (Devereux, 2011; Edmonds et al., 2005; Duflo, 2000) and provides some opportunity for younger individuals to convert grant income into secondary income through entrepreneurial activity (Burger et al., 2009). In the South African context, there are high barriers to entry into the informal sector, including capital/land/credit constraints, and the prevalence of violence and insecurity in the informal sector (Kingdon and Knight, 2004). Under the conditions of very high involuntary unemployment, it has been recommended that - in addition to the category of "narrow" unemployment, which refers to active search and is most com- 
monly used in South Africa - "broad" unemployment should be also considered, with "broad" referring to those without work who say they would accept a job if they were offered one (Sienaert, 2008; Williams, 2007). The presence of recipient pensioners (in particular grandmothers) enables prime-aged mothers to afford the costs associated with urban migration and an active job search and makes it possible for grandmothers to support and look after grandchildren (Neves et al., 2009; Samson, 2009; Posel et al., 2006; Keswell, 2004). Neves and colleagues (2009) describe this process as an "outsourcing" of the often unacknowledged caring and domestic roles in the household to the poorest, which frees others in the chain to engage with the labour market.

While the relatively smaller Child Support Grant, primarily received by working-age women, is clearly not intended as an employment support scheme, a number of studies have examined its impact on labour market participation as an ancillary outcome (Samson, 2009). Available evidence provides strong confirmation that social grants do not create dependency and that any potential disincentives coexist with stronger positive effects (Williams, 2007). This means that social grants are much more likely to help in job search and income generation rather than in leading to reduced economic activity. The majority of CSG recipients have no regular wage employment (Patel et al., 2012; Hall and Wright, 2010). Yet even against this backdrop of high female unemployment, care responsibilities and lack of skills and education, there are indications that the relatively small Child Support Grant is associated with a higher probability of female participation in the broad labour force and a higher probability of being employed. A study that took advantage of the stepwise pattern of grant receipt between 2002 and 2006, as the cut-off age for grant receipt was progressively being increased, showed that mothers who become recipients in their 20s experience a 15 per cent increase in employment probability, and a 9 per cent increase in labour force participation (Eyal and Woolard, 2011). A qualitative study in which interviews were conducted with both CSG and DG recipients in the Western Cape and Eastern Cape about the nature of their links to the labour market found no support for the idea that the Child Support Grant discouraged recipients from working. Most respondents felt that the grant was simply not enough money to affect their labour supply decisions (Surender et al., 2007). Williams (2007) found that for mothers, having a child that receives the CSG is associated with an increase of 7 to 14 per cent in broad labour participation, with the most positive effects observed amongst mothers living in informal settlements and with lower levels of education. Samson (2009) observed that male and female working-age adults not participating in the labour force, and belonging to poor households in receipt of the CSG, after a year were 3 per cent (20 per cent of transfer recipients vs. 17 per cent of non-recipients) more likely to look for work and 2 per cent (15 per cent of recipients vs. 13 per cent of non-recipients) more likely to find employment than comparable adults in non-recipient households. These effects were strongest for working-age women: after a year, receipt of the CSG was associated with a 3 per cent (15 per cent of transfer recipients vs. 12 per cent of non-recipients) higher probability of finding employment, a 6 per cent ( 20 per cent of transfer recipients vs. 14 per cent of non-recipients) higher probability of actively looking for work and a 9 per cent (65 per cent of recipients vs. 74 per cent of non-recipients) lower probability of not participating in the labour force (Samson, 2009).

Similar to the OAP, a number of channels through which the CSG may have led to improved labour market outcomes have been theorized. Within the constraints imposed 
by the small amount represented by the CSG, and the evidence that it is primarily spent on food and children's basic needs, these findings suggest that the grants may enable poor individuals to finance and alleviate constraints to job search, finance migration, manage negative shocks, fund small enterprise creation, and improve productivity through better health, nutrition and training (Devereux, 2011; Williams, 2007; Lund, 2002a; Samson et al., 2002).

Finally, it is worth citing the evidence regarding child labour. While work participation rates of children did not vary significantly with household pension status, substantial and statistically significant declines in total hours worked by rural children aged 13 to 17, when black South African families become eligible for social pension income, were documented in one study (Edmonds, 2006). The author suggested that the pension alleviates liquidity constraints such as schooling costs. A survey of adolescents commissioned by the United Nations Children's Fund (UNICEF) showed that early receipt of the Child Support Grant (in the first seven years of life) reduces the likelihood that beneficiaries, especially girls, will work outside the home when they reach adolescence (Heinrich et al., 2012). Conversely, however, in a qualitative review Devereux et al. (2011) found no evidence that the CSG is reducing the extent of children's participation in (licit or illicit) income-earning activities. Yet the authors acknowledge that to the extent that economic imperatives drive child labour, social grants that are well targeted at poor households can make a positive difference.

\subsection{Household composition and child care}

In 2005, a national household survey showed that only a third of all South African households conform to the nuclear "norm" of children and a middle generation. About a quarter have the middle generation only (including couples who have not yet had children, people or couples whose children have grown up and moved on, people who have not had children, and student households). About one-fifth are multigenerational and include children, middle generation and older people (Budlender and Lund, 2011). In 3 per cent of households the middle generation is absent altogether (ibid.), which is in line with studies showing the effects of labour migration and the large-scale impacts of HIV/AIDS (Burns et al., 2005).

Social grants intersect with social trends in household composition in a number of ways. Households that receive social transfers are on average larger than those that do not (Neves et al., 2009). Larger households are typically poorer and may therefore be more likely to apply for the grants (Burns et al., 2005). On the other hand, social pensions are associated with increases in household size and changes in household composition, with a larger number of children, especially those aged zero to six, migrating to pensioner households (Edmonds, 2006). In the South African context there is no evidence that pension receipt increases the propensity of the elderly to live alone, in contrast with studies conducted amongst wealthier populations (Edmonds, 2006; Burns et al., 2005). As shown in section 5.3, evidence of the effect of pensions on the migration of working-age adults is robust. Out-migrants are typically still considered as household members. Evidence for migration effects is strongest for older women of working age and weaker for younger women of childbearing age and for men. The study conducted by Edmonds (2006) revealed a decline in the number of women aged 30 to 39 in the household associated with pension eligibility and an increase of similar 
magnitude in women aged 18 to 23 (with a regression discontinuity effect estimate of 0.04 in both cases). There is little evidence that the pension acts as an attractor to non-resident, working-age household members, causing them to relocate into pensionreceiving households. Rather, the effect is primarily due to young workers delaying leaving grant-receiving households (Samson, 2009).

In South Africa large numbers (between 20 and 30 per cent) of children are brought up not residing with their biological mothers and in households in which other (largely female) relatives take care of them (Budlender and Lund, 2011; Delany et al., 2008). Many grandmothers care for their grandchildren, often in the absence of the children's parents. This trend is compounded by high rates of unemployment and the prevalence of HIV/AIDS. Moreover, child care remains an unpaid profession in South Africa, with almost non-existent state provision for it (Goldblatt. 2005). In these circumstances, the pension and the Child Support Grant provide an important income source through which elderly caregivers are able to meet child-care and educational costs (Burns et al., 2005). Budlender and Lund (2011) suggest that, unlike in other countries where young girls may be withdrawn from school to provide care, in South Africa it is likely that unemployed adult women and older female pensioners are filling in as caregivers. The combination of social transfers targeting both the elderly and children provides support for these arrangements. At the same time (and as also discussed in section 3.2), a note of caution is added by Neves et al. (2009), who note that while social grants strengthen networks of care, they can also potentially place even larger responsibilities for the dispensing of care on economically marginalized women, who already bear considerable burdens sustaining their households.

\subsection{Intra-household decision-making}

Patterns of resource allocation and the dynamics of decision-making within households are often affected by state transfers (Neves et al., 2009) and reflect the need for bargaining models rather than unitary household models, which take into consideration complex intra-household dynamics (Sienaert, 2008). Insights from gender studies show that access to an independent source of income can increase the power and status of an individual within a household and empower those traditionally responsible for the care of children, particularly older women who suffer the combined disadvantages of their gender and age (Barrientos and Lloyd-Sherlock, 2002). Barrientos and Lloyd- Sherlock document how receipt of the state pension increases the status of the elderly within their informal networks, cements the role of (particularly) elderly women within their otherwise marginalized households and enables them to engage in other activities such as care for grandchildren. The poorest and most marginal of the poor have weak social networks and lack tradable assets (Devereux et al., 2011). Regular cash payments such as social grants can provide bargaining power within these systems of reciprocity (Plagerson, 2010).

Ambler (2011) found that pension-eligible females were 12 to 16 per cent more likely than ineligible women (aged 50-60) to be the primary decision-makers for expenditures for both day-to-day and large or unusual purchases, but observed no corresponding effect at the age of pension eligibility for older men. These results are concentrated amongst households where the children's mother is not present, suggesting that, if the mother is present, the receipt of pension income can allow older women to transfer 
decision-making power to another person in the household, for example the child's mother (Ambler, 2011).

CSG recipients typically collect and manage the grants and report relatively high levels of financial decision-making autonomy (Delany et al., 2008; De Koker et al., 2006). The grant supports women's ability to control and allocate resources, with a positive impact on household food security (Patel and Hochfeld, 2011). Women place great importance on welfare-related goals and express their desire to use their influence and resources to promote the needs of their household and children (Vorster and De Waal, 2008). A larger proportion of rural and informally-employed urban resident women indicate being involved in financial decision-making than do women in formal urban employment, a dynamic that probably reflects the greater likelihood of resident male partners in the latter group (Neves et al., 2009). Despite only small shifts in gender relations, the impacts of HIV and increased dependence on women's incomes, the Child Support Grant does ease women's burden of care and responsibility for household and child survival. At the same time, however, women remain largely responsible for caring and looking after families, with few signs of increase in men's participation in genderexchanged roles. Social transfers do not on their own transform gender relations (Patel and Hochfeld, 2011; Lund, 2008b).

In contexts where households receive both pensions and CSGs, some interesting observations have emerged. Møller (2010) argues qualitatively that the introduction of the Child Support Grant has increased the numbers and generations of income earners in poor households. Younger mothers in the middle generation are now income earners and share the financial burden of raising children in multi-generation households, when previously pensioners were the sole earners in the household (Møller, 2010). Conversely, research by Goldblatt (2005) reported instances of intergenerational conflict (between younger and older women) over the CSG, with the younger women possibly seen as threatening the control older women exert over household finances (Goldblatt, 2005).

With regard to the Disability Grant, incidents are reported in which women saw the opportunity offered by the grant as a way to escape abusive partners (Goldblatt, 2005).

\subsection{Health and education}

In the long term, the relationship between social transfers and economic empowerment is mediated by investments in human capital as grants are linked to better health and education outcomes, which in turn put women in stronger economic positions. Cash transfer programmes provide a predictable and reliable source of income, which can increase the capacity of households to invest in human capital and help to break the intergenerational cycle of poverty (Woolard and Leibrandt, 2010). Access to adequate nutrition for young children is of particular concern, as nutritional deprivation and malnutrition in the early years have long-term negative consequences on physical and cognitive development (Delany et al., 2008).

A number of authors have demonstrated the health and nutrition benefits of social grants for children (Williams, 2007). In their review of impacts of the social security system in South Africa, Neves et al. (2009) found that both pensions and Child Support Grants are strongly associated with improvements in the quantity and quality of food consumption, improved anthropometric outcomes and lower levels of morbidity. 
Similarly, Samson et al. (2004) showed that social grants were effective in addressing widespread hunger, as well as basic needs in general. They observed that spending in households that receive social grants tends to be directed more to basics such as food, fuel and housing, and less to tobacco and debt. All major social grants - the OAP, the CSG, and the DG - are significantly and positively associated with a greater share of household expenditure on food. Receipt of the social pension was associated with an increase of 1.5 per cent in household spending on food, receipt of a Child Support Grant with an increase of 1.5 per cent and receipt of a Disability Grant with an increase of 2.5 per cent on food items (Samson et al., 2004).

Better anthropometric outcomes have also been observed for the social grants (Schneider et al., 2011; Agüero et al., 2006; Duflo, 2003). In the case of the Old Age Pension, findings on the nutritional and health effects are strongly affected by the gender of the recipient. Consistent with international evidence that grant receipt by women is associated with enhancing the welfare of children under the age of five, Duflo (2000, 2003) observed substantial improvements in the weight-for-height and height-for-age status of female children living with female pensioners. Pensions received by women improved the height-for-age z-scores of younger girls by at least 1.16 standard deviations, and the weight-for-height z-scores of girls by 1.19 standard deviations. There was little corresponding effect for male children, and no effect for male pensioners (Duflo, 2000; Duflo, 2003). A subsequent study similarly confirmed that the increase in female decision-making power translates into positive household level impacts, and that female (but not male) pension eligibility results in an increase in young girls' weight-for-height measurements (Ambler, 2011).

The links between pension receipt and health benefits are also related to whether the income is pooled within the household. Case (2001) investigated the impact of Old Age Pensions on health status. The study showed that OAP income was pooled in 84 per cent of households. Where income was not pooled, beneficial health impacts were limited to only the pensioner. Where income was pooled, children reported improved anthropometric outcomes, suggesting a beneficial impact beyond the pensioner. The study suggested that this impact works partly through improved sanitation, partly through improved nutritional status, and partly through reduction in psychosocial stress.

A further positive health outcome associated with the CSG, is the substantial reduction of unsafe partner selection by adolescent girls. The author of the study that showed this result concluded that child-focused cash transfers may be considered an important component of effective combination strategies for the prevention of HIV (Cluver et al., 2013).

School enrolment rates are extremely high in South Africa and generally undifferentiated by gender ( 98 and 99 per cent between the ages of 7 and 13, and 92 per cent on average between the ages of 14 and 17 in 2007) (Neves et al., 2009; Delany et al., 2008). Despite this high base, available evidence suggests that South Africa's social transfers are important for the welfare of children, even when they are unintended beneficiaries (as in the case of pensions). Various studies have observed a positive association between improved school enrolment rates and receipt of both the pension (Woolard et al., 2011; Edmonds, 2006; Hamoudi and Thomas, 2005) and the Child Support Grant (Williams, 2007; Budlender and Woolard, 2006; Case et al., 2005; Samson et al., 2005; Samson et al., 2004). For example, Williams (2007) concluded that the increase in school attendance associated with the (then unconditional) Child Support 
Grant was considerably larger than the effect reported by Skoufias for the Progresa conditional cash transfer programme in Mexico, in which grant payment is conditional on a child's school enrolment and attendance (Williams, 2007). Whereas Skoufias found that Progresa increased primary school enrolment by 0.74 to 1.07 per cent for boys and by 0.96 to 1.45 per cent for girls (from a base of 90 to 94 per cent), Williams found that the Child Support Grant increased primary school enrolment by 2.4 per cent from a base of 95.6 per cent (using the 2005 General Household Survey).

Conversely, Delany et al. (2008) did not find an association between school attendance and receipt of the Child Support Grant. With regard to the gender dimensions of findings on schooling and cash transfers, Edmonds (2006) identified increases in school attendance and completed schooling (amongst children over the age of five) when a household member becomes pension eligible. In this study, unlike other studies showing greater effects for female pensioners, the effects are limited to pension-eligible men, a result that Edmonds attributes to greater cash constraints (such as for example limited access to credit programmes) for elderly black males living in rural areas, affecting schooling costs. Another study found that having a female pensioner mitigates the impact of orphanhood with regard to enrolment and progression but does not do so with regard to school-related expenses. Some authors found that having a male pensioner in the household had a negative effect on school progression, and an insignificant effect on enrolment and school-related expenditure (Case and Ardington, 2006). Hamoudi and Thomas (2005) found that pension income has a greater beneficial impact on girls' education than boys' education. A study by Heinrich et al. (2012) analysed adolescent absences from school and provided evidence of the impact of the Child Support Grant on schooling outcomes for adolescents. A household's receipt of the CSG reduced adolescent absences from school, particularly for male adolescents, even when the household did not receive the grant specifically for the adolescent (Heinrich et al., 2012).

Early receipt (from birth) of the CSG was found to be a significant factor, increasing girls' grade attainment compared to those receiving the grant only at six years of age. Girls receiving the grant early completed one quarter of a grade more compared to those receiving the CSG from age six. The impact was largely the result of early receipt, which reduced delays in girls entering school, with girls enrolling early obtaining higher scores in mathematics and reading tests. For children whose mothers have fewer years of education the impacts were even greater, suggesting that the Child Support Grant plays a compensatory role for children with less educated mothers, narrowing the schooling gap between children whose mothers have less education and those who have more (Heinrich et al., 2012).

Beyond statutory education, a link has been found between CSG receipt and pre-school attendance (Delany et al., 2008; Devereux et al., 2011). CSG recipients report that the grant enables them to send their children to pre-school or crèche, allowing them to cover school fees and additional costs such as transport, clothes, toiletries and food. Many argue that without the grant they would not be able to afford this vital service (Devereux et al., 2011).

\subsection{Fertility rates}

An aspect of cash transfers that has a strong gender dimension is the common concern of a link between the introduction of a cash transfer programme (particularly child ben- 
efits) and teenage pregnancy. If this concern were substantiated, there would also be implications for the relationship between cash transfers and employment of women in particular.

The belief that grants incentivize childbirth is frequently cited in South Africa, mostly in relation to the Child Support Grant. Related concerns are a lack of responsibility amongst young mothers for their children and inappropriate use of the grants for personal consumption (Neves et al., 2009). Yet the body of evidence refuting these claims is now well established and convincing, suggesting that anecdotal cases of grant abuse publicized in the media provide an inaccurate portrayal of the reality, namely that the vast majority of mothers use the grant in ways that are beneficial for their children and households (Goldblatt, 2005).

Evidence contesting the existence of a perverse incentive for increased fertility amongst young women is multi-faceted and supports the intuitive assumption that a relatively small benefit would be unlikely to have a significant effect on reproductive decisionmaking in light of the considerable psychological effort, time and monetary investment required for childbearing and child-raising (Neves et al., 2009). First, fertility rates for teenage girls rose rapidly in the 1980s, then declined before the introduction of the Child Support Grant in 1998 and have since remained stable despite the presence of the grant (Makiwane, 2010, Neves et al., 2009). Second, teenage uptake of the grant is much lower than the teenage pregnancy rate (Makiwane, 2010). Third, only a small minority of CSG recipients are teenagers, and parents of grant-receiving children are older than average (Case et al., 2005). Fourth, the data indicate that children whose mothers are present are more likely ( 44 per cent) to receive a grant relative to those whose mothers are not present (38 per cent) (ibid.), thus countering the concern that mothers receive the grant while abandoning their children to the care of others.

Summarizing, Makiwane et al. (2010) conclude that the findings of their study "do not suggest any significant positive association between the grant and the trend in teenage childbearing in South Africa during the past decade". An impact evaluation review of the Child Support Grant showed that early receipt of the grant by children and receipt of the grant in the household at the time of adolescence are important in protecting adolescents against risky behaviours and early pregnancy (Heinrich et al., 2012). Lastly, a study investigating the relationship between pensions and fertility in five sub-Saharan countries concluded that overall results indicated that having a high-coverage pension system is associated with a reduction in the fertility rate in the range of 0.5 to 1.5 children per woman (Holmqvist, 2010). 



\section{Conclusion and recommendations}

\subsection{Conclusion}

South Africa's cash transfer system has a strong poverty alleviation focus, targeting particularly vulnerable groups such as the old, the young and those living with disabilities. Social assistance has expanded considerably, and the cash transfer system is extensive both in terms of expenditure and coverage. Even though working-age women are not intended to be direct beneficiaries of social assistance, many receive grants on behalf of their child(ren), while there also tends to be an overrepresentation of women amongst pension and disability grant recipients. Extensive research and evaluation of the grants in South Africa have shown that transfers have many positive effects for grant beneficiaries (especially women) and their families. As discussed in Part 5, grants increase incomes and hence decrease poverty amongst the poorest households, just as grants correlate with better health and education outcomes.

The main finding of the paper is that, while cash transfer recipients still remain largely at the margins of the labour market, there are some indications that receipt of cash grants can empower women both in terms of intra-household decision-making and with regard to accessing the labour market and engaging in income-generating activities. In the same vein, research has shown that grants can neither be linked to disincentives to work nor to higher fertility rates amongst young women. Beyond the cash transfer system, a few other positive developments in South Africa from a gender perspective are worth mentioning: the extension of the UIF and set minimum wages for domestic workers, the increase in employment amongst women in general, and the extension of the public works programmes to include social sectors that are usually accessed by women.

However, these positive developments must be counter-weighted by other prevailing aspects of the cash transfer system and broader policy areas. It is clear from the above review that while more women are employed, women are still overrepresented amongst the unemployed and amongst those working in informal, precarious and low-paid jobs with limited access to social security. The EPWP may have been extended into the social sectors, but the job opportunities offered are temporary, with low pay and with little opportunity for subsequent employment, particularly as the social sectors providing care are poorly developed and supported across the country. Hence, care of the old, young and ill is still largely left to women within the household - and they are expected to play the double role of active labour market participants and unpaid domestic caregivers. Thus, while women are able to partly channel the grants to access the labour market, invest in assets or develop income-generating activities, possible positive consequences for them are mostly coincidental. It is possible that the cash transfer system would have a greater impact for women if care facilities and social services were better developed, which could relieve them of some domestic responsibilities. However, institutional care facilities are scarce, particularly in rural areas, and while in theory there is an automatic link between grant receipt and, for instance, school fee exemption, in practice there is often ignorance of the possibility of access to free or subsidized services, or they are often not requested or implemented. 


\subsection{Recommendations}

\section{- Gender as a central social protection objective}

It is clear from the above that gender is not a general objective of social protection in South Africa. The assumption seems to be that the grants system will also benefit women and hence lead to greater gender justice, while women are in fact striking a difficult balance between providing care in the domestic sphere and earning an income in the formal or informal economy. It is crucial to align gender equality goals with social protection. This means that in the design of social protection policies we should ensure that social protection achieves both gender equality and social development. To the extent that social protection policies address structural gender inequalities, social protection will take a transformational role, and not just a protective, preventive or promoting role. Understanding gender dynamics and the impacts of social protection systems more broadly also involves developing a greater understanding of the role of men in social protection. Gender-neutrality and the progressive expansion of the grants system in South Africa are important features and admirable developments in terms of moving towards the realization of social and economic rights. It is therefore critical that the grants system be integrated with other efforts that can support gender equality and social development; such as for instance recognizing and rewarding women for their extensive care work.

\section{- A broad and integrated approach to social protection}

Cash transfer programmes should be seen as one component of a much broader set of social protection instruments. They should not replace the public provision of essential goods and services (see next point) and should be better integrated with social insurance programmes. Lund suggests that "an approach to social security is needed which sees economically active people as placed at different points on a continuum from formal to informal employment [...] and which keeps open a role for multiple stakeholders, especially employers and owners of capital in extending social security coverage to informal and non-standard workers" (Lund, 2002b).

\section{- Links to essential services}

It is important to invest in well-functioning and accessible public health, education, and care services. If these services are adequately financed and have extensive coverage, they can relieve women of many domestic activities and also become a source of decent employment (for both women and men). Similarly, public provision of a range of complementary goods and services such as clean water, subsidized food items, sanitation, electricity, transport and housing can also reduce the burden of unpaid domestic responsibilities that is very often disproportionately assigned to women and girls. The scaling up of coverage and access to basic services will go a long way in improving the impact of grants in South Africa.

\section{- Promoting employment}

Grants in South Africa reach 17 million households, many of which are affected by unemployment. The creation of decent employment for women and men in South Africa 
is a tremendous challenge that requires multiple strategies, and cash transfers should not be expected to be the panacea for all social problems. However, cash transfers can offer important opportunities to promote economic participation amongst marginalized households. Cash transfers also provide simple and effective administrative systems that can be used to promote direct job creation through initiatives including: enhanced employability through access to training programmes, job search facilitation, support for the self-employed and the stabilization of existing livelihoods (Altman and Boyce, 2008). An initiative that would complement the CSG would be to link employment creation more directly to child care: where ECD services exist, CSG recipients could additionally receive vouchers for each child beneficiary to receive ECD services (Jacobs et al., 2010).

\section{- Overcoming the rural-urban divide.}

Straddling the rural-urban divide at the intersection between home and work is a crucial issue, especially for women. Policies reducing regional immobility and increasing jobseeking activities amongst the unemployed need to be considered. While policy solutions are not obvious, some issues deserve a closer look. First, financial and other assistance for jobseeking and relocation might be one way to overcome unemployment, affecting many in rural areas. Second, one could specifically target unemployed rural men and women for training, housing and public works programmes to enable their transition into urban labour markets. Last, given involuntary rural unemployment levels, efforts could be focused on reviving small-scale agriculture initiatives, supporting labour demand from larger farms and creating casual labour markets in rural areas. These steps would also need to be complemented by other policies (such as infrastructure and household policies) to facilitate casual labour markets in rural areas (Klasen and Woolard, 2008). 



\section{References}

Agüero, J.; Carter, M.; Woolard, I. 2006. The impact of unconditional cash transfers on nutrition: The South African Child Support Grant, University of California at Riverside, online. Available at: http://www.cgdev.org/doc/events/11.07.06/unconditional\%20cash\%20transfers.pdf [Accessed 29.11.07].

Alliance for Children's Entitlement to Social Security (ACESS). 2007. What does the law say about eligibility for school fees exemption? Available at: http://www.acess. org.za/index.php?option=com_content\&view=article\&id=97:media-statements-from2002-to-2009\&catid=901\&Itemid $=48$.

Altman, M.; Boyce, G. 2008. Policy options to leverage the system of social grants for improved access to economic opportunity, Paper prepared for the Department of Social Development (Pretoria, Human Sciences Research Council).

Ambler, K. 2011. Bargaining with Grandma: The impact of the South African pension on household decision making, Population Studies Center Research Report 11-741 (Ann Arbor, University of Michigan, Institute for Social Research).

Ardington, C.; Case, A.; Hosegood, V. 2009. "Labor supply responses to large social transfers: Longitudinal evidence from South Africa", in American Economic Journal: Applied Economics, No.1, pp. 22-48.

Ardington, E.; Lund, F. 1995. "Pensions and development: Social security as complementary to programmes of reconstruction and development", in Development Southern Africa, No. 12, pp. 557-577.

Barrientos, A.; Lloyd-Sherlock, P. 2002. Non-contributory pensions and social protection, Issues in Social Protection Series (Geneva, ILO).

Bentley, K. 2004. "Women's human rights and the feminisation of poverty in South Africa", in Review of African Political Economy, No. 31, pp. 247-261.

Bertrand, M.; Mullainathan, S.; Miller, D. 2003. "Public policy and extended families: Evidence from pensions in South Africa", in The World Bank Economic Review, No. 17, 27-50.

Brockerhoff, S. 2010. Monitoring the progressive realisation of socio-economic rights: A review of the development of social security policy in South Africa (Johannesburg, Studies in Poverty and Inequality Institute).

Budlender, D. 2009. Towards minimum wages and employment conditions for the Expanded Public Works Programme Phase /I (Johannesburg, Community Agency for Social Enquiry).

-; Lund, F. 2011. "South Africa: A legacy of family disruption", in Development and Change, No. 42, pp. 925-946.

-; Woolard, I. 2006. The impact of South African Child Support and Old Age grants on children's schooling and work, International Programme on the Elimination of Child Labour (Geneva, ILO). 
Burger, R.; Von Fintel, D.; Grün, C. 2009. The nexus between social grants and participation rates: Dynamics across generations in the South African labour market (Pretoria, National Planning Commission).

Burns, J.; Keswell, M.; Leibbrandt, M. 2005. "Social assistance, gender, and the aged in South Africa", in Feminist Economics, No. 11, pp. 103-115.

Casale, D.; Posel, D. 2002. "The continued feminisation of the labour force in South Africa", in South African Journal of Economics, No. 70, pp. 156-184.

-; Posel, D. 2005. "Women and the economy: How far have we come?", in Agenda: Empowering women for gender equity, No. 19, pp. 21-29.Case, A. 2001. Health, income and economic development, Paper presented at ABCDE conference, May 2001 (Washington DC, World Bank).

-; Ardington, C. 2006. "The impact of parental death on school enrolment and achievement: Longitudinal evidence from South Africa", in Demography, No. 43, pp. 401-420.

-; Deaton, A. 1998. "Large cash transfers to the elderly in South Africa", in Economic Journal, No. 108, pp. 1330-1361.

—; Hosegood, V.; Lund, F. 2005. "The reach and impact of Child Support Grants: Evidence from KwaZulu-Natal”, in Development Southern Africa, No. 22, pp. 467-482.

Cluver, L.; Boyes, M.; Orkin, M.; Pantelic, M.; Molwena, T.; Sherr,L. 2013 "Childfocused state cash transfers and adolescent risk of HIV infection in South Africa: a propensity-score-matched case-control study", in The Lancet, No. 1, pp e362-e370.

De Koker, C.; De Waal, L.; Vorster, J. 2006. A profile of social security beneficiaries in South Africa, commissioned by Department of Social Development (Datadesk, Stellenbosch University).

Delany, A.; Ismail, Z.; Graham, L.; Ramkisson, Y. 2008. Review of the Child Support Grant: Uses, implementation and obstacles (Johannesburg, Department of Social Development/ CASE/ SASSA/UNICEF).

Devereux, S. 2011. "Social protection in South Africa: Exceptional or exceptionalism?", in Canadian Journal of Development Studies/Revue canadienne d'études du développement, No. 32, pp. 414-425.

—; Adato, M.; Sabates-Wheeler, R.; McConnell, J.; Becker, E. 2011. Child Support Grant Evaluation 2010: Qualitative Research Report (Pretoria, Department of Social Development).

Dinkelman, T. 2004. "How household context affects search outcomes of the unemployed in KwaZulu-Natal, South Africa: A panel data analysis", in South African Journal of Economics, No. 72, pp. 484-521.

DoL, 2015. Quarterly Labour Force Survey. Quarter 4, 2014 (Pretoria, Department of Labour).

Du Toit, A.; Neves, D. 2007. Understanding self-employment at the margins of the South African economy: Findings from a pilot study on qualitative approaches to selfemployment, Report for the National Income Dynamics Study Steering Committee, Office of the Presidency (Bellville, PLAAS). 
Duflo, E. 2000. Child health and household resources in South Africa: Evidence from the Old Age Pension Program", in The American Economic Review, No. 90, pp. 393-398.

—; 2003. "Grandmothers and granddaughters: Old-age pensions and intrahousehold allocation in South Africa", in The World Bank Economic Review, No. 17, pp. 1-25. Edmonds, E. 2006. "Child labor and schooling responses to anticipated income in South Africa", in Journal of Development Economics, No. 81, pp. 386-414.

—; Mammen, K.; Miller, D. 2005. "Rearranging the family? Income support and elderly living arrangements in a low income country", in Journal of Human Resources, No. 40, pp. 186-207.

Eyal, K.; Woolard, I. 2011. Female labour force participation and South Africa's Child Support Grant, CSAE 25th Anniversary Conference 2011: Economic Development in Africa, 8 March 2011, University of Cape Town.

Goldblatt, B. 2005. "Gender and social assistance in the first decade of democracy: A case study of South Africa's Child Support Grant", in Politikon, No. 32, pp. 239-257.

-. 2009. "Gender, rights and the Disability Grant in South Africa", in Development Southern Africa, No. 26, pp. 369-382.Gordhan, P. 2013. Budget Speech, 27 February 2013 (Cape Town, National Treasury).

Gordhan, P. 2014. Budget Speech, 26 February 2014 (Cape Town, National Treasury).

-. 2013. Budget Speech, 27 February 2013 (Cape Town, National Treasury).

Goudge, J.; Russel, S.; Gilson, L. 2009. "IIIness-related Impoverishment in rural South Africa: Why does social protection work for some households but not for others?", in Journal of International Development, No. 21, pp. 231-251.

Graham, L.; Moodley, J.; Selipsky, S.; Rowland, W. 2010. Poverty and disability in Johannesburg, CSDA Monograph Series (Johannesburg, University of Johannesburg).

Grosh, M.; Del Ninno, C.; Tesliuc, E.; Ouerghi, A. 2008. For protection and promotion: The design and implementation of effective safety nets (Washington DC, World Bank).

Hall, K.; Wright, G. 2010. "A profile of children living in South Africa in 2008", in Studies in Economics and Econometrics, No. 34, pp. 45-68.

Hamoudi, A.; Thomas, D. 2005. Pension income and the well-being of children and grandchildren: New evidence from South Africa, Paper CCPR-043-0 (Los Angeles, California Center for Population Research).

Hassim, S. 2006. "Gender equality and developmental social welfare in South Africa", in S. Razavi and S. Hassim (eds): Gender and social policy in a global context: Uncovering the gendered structure of the "social" (Basingstoke, Palgrave).

Heinrich, C.; Hoddinott, J.; Samson, M.; Mac Quene, K.; Van Niekerk, I.; Renaud, B. 2012. The South African Child Support Grant Impact Assessment (Pretoria, UNICEF/ SASSA/DSD).

Holmes, R.; Jones, N. 2010. Social protection programming: The need for a gender lens, Briefing Paper 63 (London, Overseas Development Institute). 
Holmqvist, G. 2010. Fertility impact of social transfers in sub-Saharan Africa - What about pensions? BWPI Working Paper 119 (Manchester, Brooks World Poverty Institute).

International Labour Office (ILO). 2010. World Social Security Report 2010/11: Providing coverage in times of crisis and beyond (Geneva).

Inder, B.; Maitra, P. 2004. Social pensions, migration and household composition: Evidence from South Africa, Discussion Paper (Roodeport, Monash University, Department of Economics).

Jacobs, P.; Baiphethi, M.; Ngcobo, N.; Hart, T. 2010. The potential of social grants expenditure to promote local economic development and job creation (Pretoria, Centre for Poverty, Employment and Growth, Human Sciences Research Council).

Jensen, R. 2003. "Do public transfers displace the value of private transfers? Evidence from South Africa", in Journal of Public Economics, No. 88, pp. 89-112.

Keswell, M. 2004. Social networks, extended families, and consumption smoothing: Field evidence from South Africa, Working Paper No. 58 (Cape Town, University of Cape Town, Centre for Social Science Research).

Kingdon, G.; Knight, J. 2004. "Unemployment in South Africa: The nature of the beast", in World Development, No. 32, pp. 391-408.

Klasen, S.; Woolard, I. 2008. "Surviving unemployment without state support: Unemployment and household formation in South Africa", in Journal of African Economies, No. 18, pp. 1-51.

Lam, D.; Leibbrandt, M.; Ranchhod, V. 2005. Labor force withdrawal of the elderly in South Africa (Cape Town, University of Cape Town, Department of Economics).

Lund, F. 2002a. “'Crowding In' care, security, and micro-enterprise formation: Revisiting the role of the State in poverty reduction and development", in Journal of International Development, No. 14, pp. 681-694.

- 2002b. "Social security and the changing labour market: Access for non-standard and informal workers in South Africa", in Social Dynamics: A Journal of African studies, No. 28, pp. 177-206.

-. 2006a. "Gender and social security in South Africa", in V. Padayachee (ed.): The development decade? Economic and social change in South Africa 1994-2004 (Pretoria, HSRC Press).

—. 2006b. "Working people and access to social protection", in S. Razavi and S. Hassim (eds): Gender and social policy in a global context: Uncovering the gendered structure of the "social" (Basingstoke, Palgrave).

- 2008a. Changing social policy: The Child Support Grant in South Africa (Cape Town, HSRC Press).

-. 2008b. "Paradoxes of social policy reform in South Africa", in The Social Work Practitioner-Researcher, No. 20, pp. 137-153.

—. 2011. "A step in the wrong direction: Linking the South Africa Child Support Grant to school attendance", in Journal of Poverty and Social Justice, No. 19, pp. 5-14. Maitra, P.; Ray, R. 2003. "The effect of transfers on household expenditure pat- 
terns and poverty in South Africa", in Journal of Development Economics, No. 71, pp. 23-49.

Makiwane, M. 2010. "The Child Support Grant and teenage childbearing in South Africa", in Development Southern Africa, No. 27, pp. 193-204.

Marais, H. 2011. South Africa pushed to the limit: The political economy of change (Cape Town, UCT Press).

Møller, V. 2010. "Strengthening intergenerational solidarity in South Africa: Closing the gaps in the social security system for unemployed youth - A case study of the "perverse Incentive'”, in Journal of Intergenerational Relationships, No. 8, pp. 145-160.

- 2011. Perceptions of fortune and misfortune in older South African households: Social pensions and the "Good Life" (Grahamstown, Rhodes University, Institute of Social and Economic Research).Neves, D.; Samson, M.; Van Niekerk, I.; Hlatshwayo, S.; Du Toit, A. 2009. The use and effectiveness of social grants in South Africa (Cape Town, FinMark Trust, Institute for Poverty, Land and Agrarian Studies, Economic Policy Research Institute).

Patel, L. 2012. "Poverty, gender and social protection: Child Support Grants in Soweto, South Africa", in Journal of Policy Practice, No. 11, pp. 106-120.

—. Forthcoming. "Social protection in South Africa: History, goals and strategies", in J. Midgley and D. Pichaud (eds): Social protection, economic growth and social change: Goals, issues and trajectories in Brazil, China, India and South Africa (Cheltenham, Edward Elgar).

—; Hochfeld, T. 2011. "It buys food but does it change gender relations? Child Support Grants in Soweto, South Africa", in Gender and Development, No, 19, pp. 229-240.

-; -; Moodley, J.; Mutwali, R. 2012. The gender dynamics and Impact of the Child Support Grant in Doornkop, Soweto (Johannesburg, University of Johannesburg, Centre for Social Development in Africa).

Plagerson, S. 2010. "Does money matter for mental health? Evidence from the Child Support Grants in Johannesburg, South Africa", in Global Public Health, forthcoming.

Posel, D.; Rogan, M. 2012. "Gendered trends in poverty in the post-apartheid period, 1997-2006", in Development Southern Africa, No. 29, 96-113.

_; Fairburn, J.; Lund, F. 2006. "Labour migration and households: A reconsideration of the effects of the social pension on labour supply in South Africa", in Economic Modeling, No. 23, 836-853.

Republic of South Africa (RSA). 1996. Constitution of the Republic of Africa. No 108 of 1996 (Pretoria, Government Printing Works).

—. 1997. White Paper for Social Welfare. Government Gazette No. 18166 (Pretoria, Department of Welfare).

—. 2013. Budget Review 2013 (Pretoria, National Treasury).

Ranchhod, V. 2006. "The effect of the South African Old Age Pension on labour supply of the elderly", in South African Journal of Economics, No. 74, pp. 725-744. 
Sabates-Wheeler, R.; Roelen, K. 2011. "Transformative social protection programming for children and their carers: A gender perspective", in Gender and Development, No. 19, pp. 179-194.

Samson, M. 2009. "Social cash transfers and employment: A note on empirical linkages in developing countries", in OECD (ed.): Promoting pro-poor growth: Employment (Paris).

-; Mac Quene, K.; Van Niekerk, I. 2005. Addressing inequality: Policies for inclusive development - a case study of social security in South Africa (Cape Town, Economic Policy Research Unit).

-; Babson, O.; Haarmann, C.; Haarmann, Khathi G.; Mac Quene, K.; Van Niekerk, I. 2002. Social security reform and the Basic Income Grant for South Africa, Report commissioned by the ILO (Cape Town, Economic Policy Research Institute).

-; Lee, U.; Ndlebe, A.; Mac Quene, K.; Van Niekerk, I.; Gandhi, V.; Harigaya, T.; Abrahams, C. 2004. The social and economic impact of South Africa's social security system (Cape Town, Economic Policy Research Institute).

South African Social Security Agency (SASSA). 2011. You and your grants 2011/12 (Pretoria).

-. 2014. Fact sheet, Issue No 9 of 2014, 30 Sep. (Pretoria).

-. 2013. Fact sheet, Issue No 3 of 2013, 31 Mar. (Pretoria).

Schneider, M.; Waliuya, W.; Munsanje, J. 2011. "Reflections on including disability in social protection programmes", in IDS Bulletin, No. 42, pp. 38-44.

Sienaert, A. 2008. The labour supply effects of the South African State Old Age Pension: Theory, evidence and implications (Cape Town, University of Cape Town, Southern Africa Labour and Development Research Unit).

Statistics South Africa. 2012. Census 2011: Census in brief (Pretoria).

—. 2013. Quarterly Labour Force Survey, Quarter 1, 2013 (Pretoria).

Steele, M. 2006. Report on incentive structures of social assistance grants in South Africa (Pretoria, Department of Social Development).

Surender, R.; Ntshongwana, P.; Noble, M.; Wright, G. 2007. Employment and social security: A qualitative study of attitudes towards the labour market and social grants (Pretoria, Department of Social Development).

—; Noble, M.; Wright, G.; Ntshongwana, P. 2010. "Social assistance and dependency in South Africa: An analysis of attitudes to paid work and social grants", in Journal of Social Policy, No. 39, pp. 203-221.

United Nations Development Programme (UNDP). 2013. Human Development Report 2013: The rise of the South: Human progress in a diverse world (New York).

Valodia, I. 2001. "Economic policy and women's informal work in South Africa", in Development and Change, No. 32, pp. 871-892.

Van der Westhuizen, C.; Sumayya, G.; Oosthuizen, M. 2007. Women in the South African labour market 1995-2005, Working Paper 06/118 (Cape Town, University 
of Cape Town, Development Policy Research Unit). http://www.chp.ac.za/research/ maternalearlychild/Pages/default.aspx.

Vorster, J.; De Waal, L. 2008. "Beneficiaries of the Child Support Grant: Findings from a national survey", in The Social Work Practitioner-Researcher, No. 20, pp. 233-248.

Williams, M. 2007. The social and economic impacts of South Africa's Child Support Grant (Cape Town, Economic Policy Research Institute).

Woolard, I.; Leibbrandt, M. 2010. The evolution and impact of unconditional cash transfers in South Africa (Cape Town, University of Cape Town, Southern Africa Labour and Development Research Unit).

-; Harttgen, K.; Klasen, S. 2011. "The history and impact of social security in South Africa: Experiences and lessons", in Canadian Journal of Development Studies/Revue canadienne d'études du développement, No. 32, pp. 357-380. 


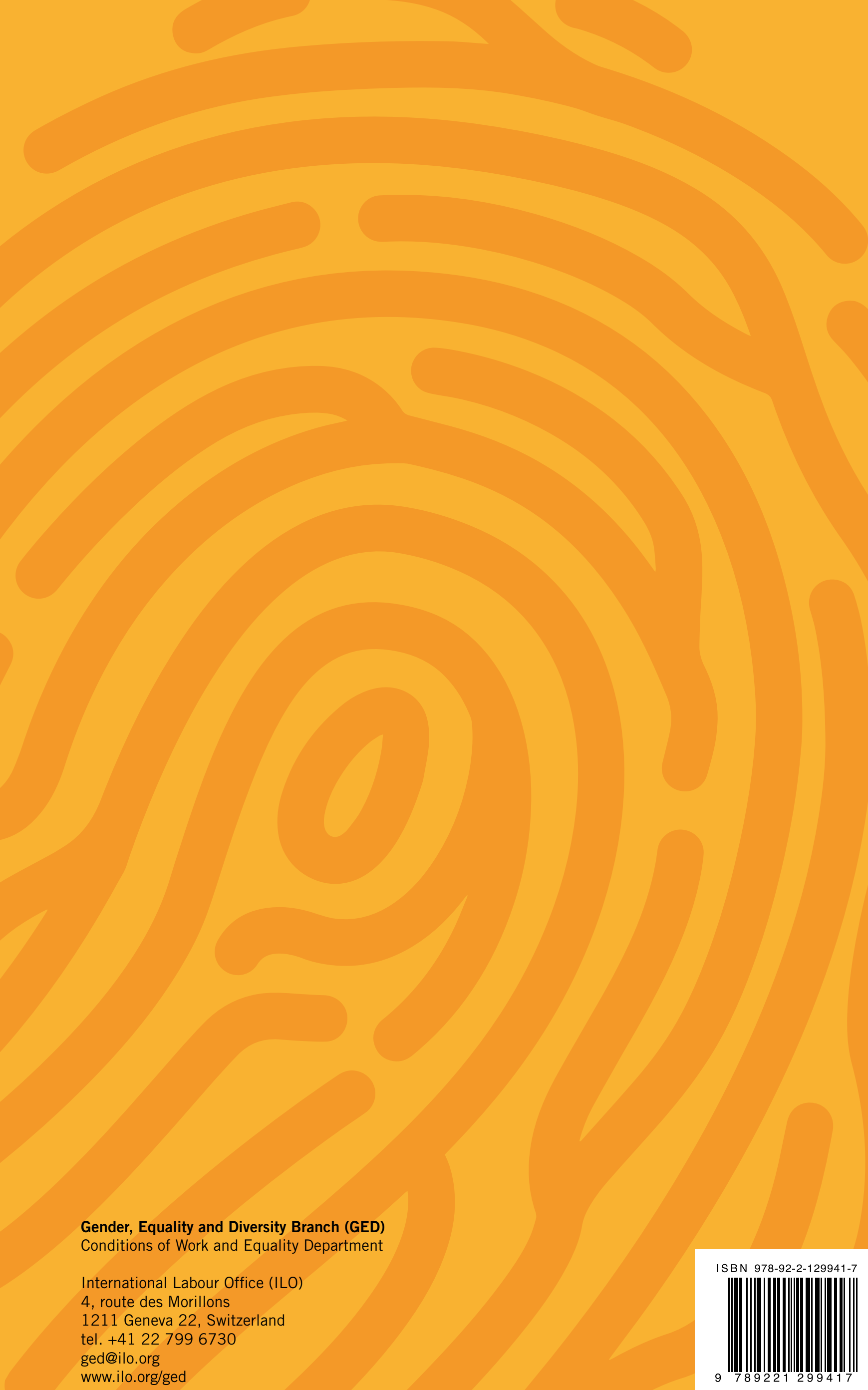

